\title{
Geoperspective
}

\section{Oil and Gas in the Netherlands - Is there a future?}

\section{R. Herber ${ }^{1,{ }^{*}}$ \& J. de Jager ${ }^{2}$}

1 Energy \& Sustainability Research Centre Groningen, Nijenborgh 4, 9747AG Groningen, the Netherlands.

2 Shell International Ltd, Kessler Park 1, 2288 GS Rijswijk, the Netherlands. Present address: Nassaukade 42, 2281 XD Rijswijk, the Netherlands.

* Corresponding author. Email: rien.herber@rug.nl.

Manuscript received: February 2010, accepted: May 2010

\begin{abstract}
The impact of oil and, in particular, gas fields discovered in the Dutch subsurface has been very significant. However, 50 years after the discovery of the giant Groningen gas field the Netherlands has become very mature for exploration of oil and gas, and the gas volume left to be discovered in conventional traps is insignificant compared to what has been found already. The total portfolio of conventional prospects held by the industry contains several 100s of billions of cubic metres (bcm), as reported by the Ministry of Economic Affairs, but many of these prospects are unattractive to drill because of their small size or other geologically unfavourable aspects. Hence, for planning purposes of future national gas production the risk should be taken into account that the size of the conventional portfolio is overestimated. The major E\&P companies have reduced their exploration efforts and the number of wells drilled as well as the size and total volume of discovered gas reserves has seen a steady decline over the last 10 years. Some surprises may still be in store and can occasionally add a welcome addition of gas. But the follow-up potential of new play and trapping concepts has been disappointing for many years now, and it is concluded that this is unlikely to be different in the future. Remaining conventional discoveries will mainly be in small near-field targets that as a result of technological advances made in the last few decades can be drilled with high confidence, despite their small volumes.

This leaves the so-called unconventional gas (UG) resources for a real and significant increase in the exploration potential of the Netherlands. UG resources occur outside conventional structural or stratigraphic traps in tight (low permeability) rocks and are of regional or sub-regional extent, without well-defined hydrocarbon-water contacts. The potential for Basin Centred Gas, Shale Gas and Coal Bed Methane is reviewed. As, according to present-day technology, development of UG requires very dense drilling at low costs with well spacing of a few 100s of metres, only the onshore potential can be commercial, even in the longer term.

Recent geological uplift is a characteristic for all North American commercial UG developments. Uplift helps bringing the resources close to the surface and facilitates development of fractures, which are essential for achieving commercial flow rates. This significantly reduces the area where commercial UG resources may occur in the Netherlands. In addition, sweet spots, where commercial flow rates and ultimate recovery per well can be achieved, represent only a fraction of the total 'play area'. The UG plays in the Dutch subsurface remain to be proven, and there is still a significant technical risk associated with these plays, on top of the commercial risk. Therefore, despite potentially enormous in-place gas volumes in these unconventional plays, recoverable volumes are much less. If UG resources can be proven and are commercially developable, their cumulative volume potential is estimated by us in the order of a few tens to one or two hundreds bcm of recoverable gas at best. Finally, as UG resources produce at very low rates and require large numbers of wells to develop, the environmental impact in a densely populated country like the Netherlands is enormous, and needs to be seriously considered, already in the exploration phase.

In a mature area like the Netherlands, industry focus should be on technology development to reduce risk, increase recovery, reduce cost and minimize surface impact. Cooperation between 0perators to build multi-well campaigns is therefore strongly recommended to reduce mobilisation cost. In addition, government incentives should be targeted at the development phase, in order to increase economic attractiveness for difficult reservoirs, both conventional and unconventional. In this way State and industry will both be able to maximize their returns on the remaining potential for gas and oil in the next two to three decades.
\end{abstract}




\section{Introduction}

Exploration and production of oil and especially gas in the Netherlands has been very successful over the last six decades. The discovery of the giant Groningen gas field in 1959, half a century ago, has had an impact on the Dutch economy which cannot easily be exaggerated. Since then, the Netherlands has developed into an important gas producer and exporter and is now the main 'gas hub' of Europe. Over the last 50 years, the Dutch State has received a staggering 211 billion euro in revenues from domestic gas production, with an average of 8 billion euro per year in the 80 's to an all-time peak of almost 15 billion euro in 2008, as a result of unprecedented high oil and gas prices (Ministry of Economic Affairs, 2009).

The income for the Dutch State relates to an annual gas production of some 70 to 80 billion cubic metres $(\mathrm{bcm})$ of gas per year. Gas production is expected to peak in 2010 with some $85 \mathrm{bcm}$ (Ministry of Economic Affairs, 2009). However, no significant new gas discoveries have been made for some years now, and production is expected to decline from 2010 onwards. The Netherlands has become a very 'mature' exploration arena where gas production exceeds by far the cumulative volumes of new discoveries: we are eating into our remaining reserves. The realisation that most of our underground gas and oil volumes have been found has led oil and gas companies to reduce exploration expenditure and activities. This then begs the question of what the future is of the Netherlands as a gas and oil producer. In this article we will explore what may be left to discover in conventional and more speculative hydrocarbon plays, what the outlook is for stranded 'difficult' discoveries, for unconventional hydrocarbons such as basin centred gas, coal bed methane, shale gas, and how technology may help finding and developing hydrocarbons. Finally, the incentive for the Dutch State to extending the production platform should be enormous, and we will discuss possible measures that could stimulate companies to develop some of the more "difficult" subsurface hydrocarbon resources.

\section{Oil and Gas discovered and remaining exploration potential}

\section{Gas}

As of the $1^{\text {st }}$ of January 2009, the total volume of gas found in the Netherlands is $4404 \mathrm{bcm}$, more than half of which, some $2875 \mathrm{bcm}$, is in the Groningen field alone. The total cumulative production in the Netherlands up to the $1^{\text {st }}$ of January 2009 amounts to $3059 \mathrm{bcm}$ of gas, leaving proven reserves of 1345 bcm 'in the ground' (Ministry of Economic Affairs, 2009). Most of the gas found to date is situated in developed fields. However, some $80 \mathrm{bcm}$ in 53 gas accumulations is still awaiting development. These accumulations may not yet have been developed for any of the following reasons: small size, difficult (tight) reservoir, relatively large distance to infrastructure, gas quality or location in an environmentally sensitive area. Of more than 70 other gas accumulations it is unlikely that they will be developed in the coming few years, and their volumes have not been included in the numbers above.

The current officially published range of remaining conventional exploration potential is 170 to $380 \mathrm{bcm}$ of gas, representing realistic commercially viable, risked volumes in recognised prospects in proven plays (Ministry of Economic Affairs, 2009). The wide range is an indication of the uncertainty of the volumes yet to be found. One would expect this estimate to go down over time as prospects are being drilled and undiscovered exploration potential either transfers to discovered volumes in the success cases or is annihilated due to dry wells. The observation is that the yet-to-be-found volume has indeed reduced over the years, but not by very much; much less than the volumes found in new discoveries (Fig. 1). To illustrate this: at the $1^{\text {st }}$ of January ' 91 the range of yet-to-find was 220 to $425 \mathrm{bcm}$, which is only some $50 \mathrm{bcm}$ more than today, while since 1991 some $425 \mathrm{bcm}$ of new gas volumes have been added from new discoveries (Fig.2). Based on this, one might be tempted to deem the historic estimate of the yet-to-find volume range as conservative and hence give a strong weight to today's high end of the range.

However, there are some elements to consider when making forward predictions. Firstly, while exploration potential is drilled away, new prospects continue to be identified, based on improved technology or new geological concepts. This has been particularly the case between 1990 and 2001 following the acquisition of 'wall-to-wall' 3D seismic, the large scale application of seismic imaging by depth migration and highly improved hydrocarbon charge and migration modelling. Examples are the Triassic 'fat sand' play (NAM; De Jager \& Geluk, 2007) and Lower Slochteren / Carboniferous play (Wintershall; De Wijn, 2009) in the offshore, the Chalk Hanze Field discovery in the far northern offshore (Petrocanada; Van der Molen, 2004) and the 'Ten Boer - fault-sealed' Rotliegend in NE Netherlands onshore (Fig. 3; De Jager \& Geluk, 2007). These prospects were drilled with high priority soon after identification, leaving a large part of the existing inventory untouched year on year. And although these discoveries demonstrate that new play concepts did continue to add gas volumes over the last 20 years, in most cases no follow-up potential could be realised. Only the Ten Boer fault-seal concept, which was understood as long ago as in 1990, provided significant follow-up. Consequently, the exploration potential is polarised between attractive prospects with quick throughput and another group of lower quality opportunities with generally a very long shelf-life. The latter make up the lion share of the portfolio and run the risk of never being drilled.

The published exploration potential does not contain prospects in speculative plays. Nevertheless, over the last decades, industry has tested several prospects in this category with the drill. Results were disappointing: NAM encountered 


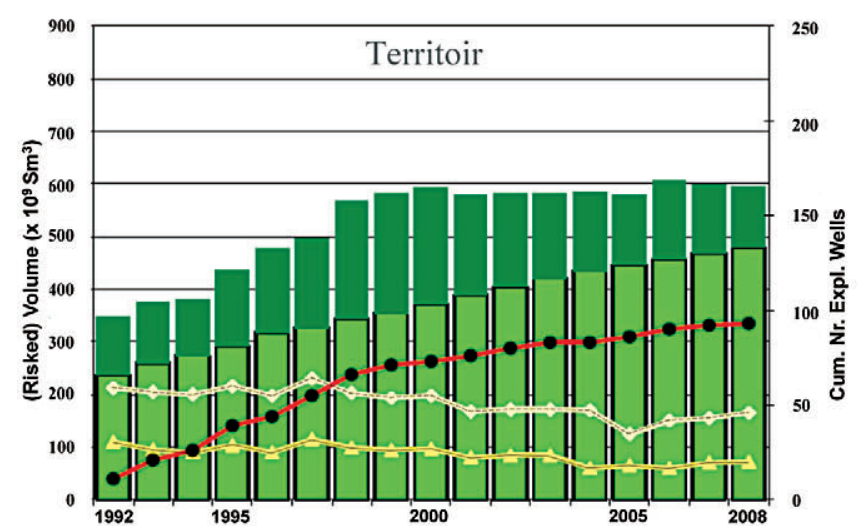

Production (ex Groningen)

Remaining reserves

Number of Exploration wells (cumulative)

High estimate Exploration potential

Low estimate Exploration potential

deep Lower Carboniferous / Devonian carbonates underneath the Groningen field in well Uithuizermeeden (Fig. 4) and Total in the Luttelgeest well in 2003 (Biteau, 2009), but both wells turned out dry. Shows of Jurassic oil but no accumulation was found by NAM in Cretaceous sands in the A14 block in 2002. It cannot be excluded that speculative plays will have some success in the future but in the last 15 years new play discoveries have not been able to provide much follow-up potential and they cannot be reliably used for forward projection of discovered volumes and Dutch production forecast.

By now the Netherlands represents a very mature exploration arena. This is clearly illustrated by the downward trend of volume of gas discovered per year, with only a meagre 5 and $3 \mathrm{bcm}$ added through new finds in 2007 and 2008 respectively (Fig. 2), and not significantly more in 2009 (personal communication G. Remmelts, TNO). Although there are still opportunities to find new gas and maybe also oil accumulations, the chances that significant new volumes are yet to be found are getting

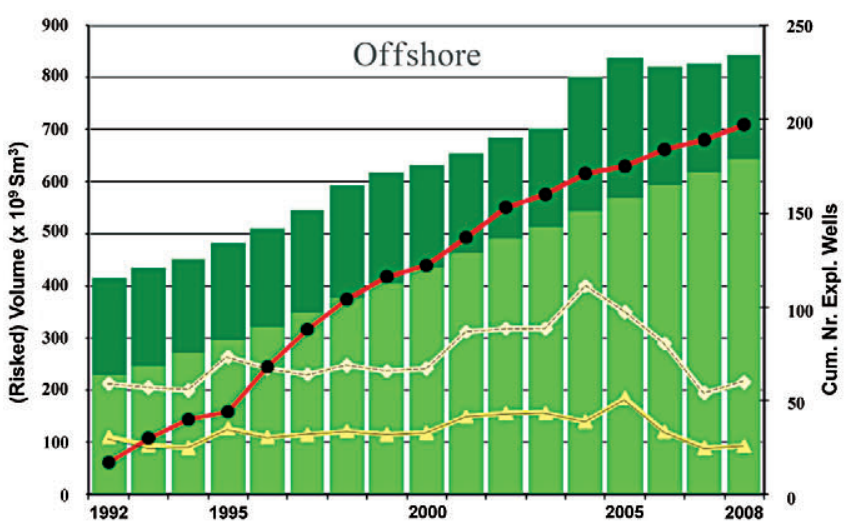

Fig. 1. Reported gas production in the Netherlands and remaining reserves for the offshore and Territoir for the period of 1992 to 2008 (excluding Groningen). Territoir includes the onshore, the Waddenzee area and a coastal strip in line with article 1 under c of the Dutch Mining Act. From: Ministry of Economic Affairs (2009).

slimmer every year. This is also illustrated in Fig. 5, which shows that in the current inventory, $50 \%$ of all opportunities has a volume smaller than $0.5 \mathrm{bcm}$ (Bokhoven, 2009). Less than $5 \%$ of all prospects have a success volume of more than $2 \mathrm{bcm}$, combined with a chance of success of $20 \%$ or more.

NAM, for many years the dominant explorer in the Netherlands, has reduced its exploration activities from drilling more than 15 exploration wells per year in the heydays of the early nineties to less than a handful of so-called near-field exploration wells currently. Total and Wintershall have also reduced their exploration activity and are now more clearly focussing on their core areas. New, mostly smaller players are however taking over. Gaz de France and others are drilling successful wells and are buying fields that do no longer fit the strategy and ambitions of the established companies. Nevertheless, the results of the activities of these new players have not been able to offset the reduced level of volumes found by the old main E\&P companies in the Netherlands.

Fig. 2. Annually discovered gas volumes in the Dutch onshore and offshore from 1990 to 2008 (based on annual reports by Ministry of Economic Affairs). There is a sharp decline in discovered volumes since the late 1990's. Preliminary information indicates that this trend has not been reversed in 2009 (personal communication G. Remmelts, TNO).

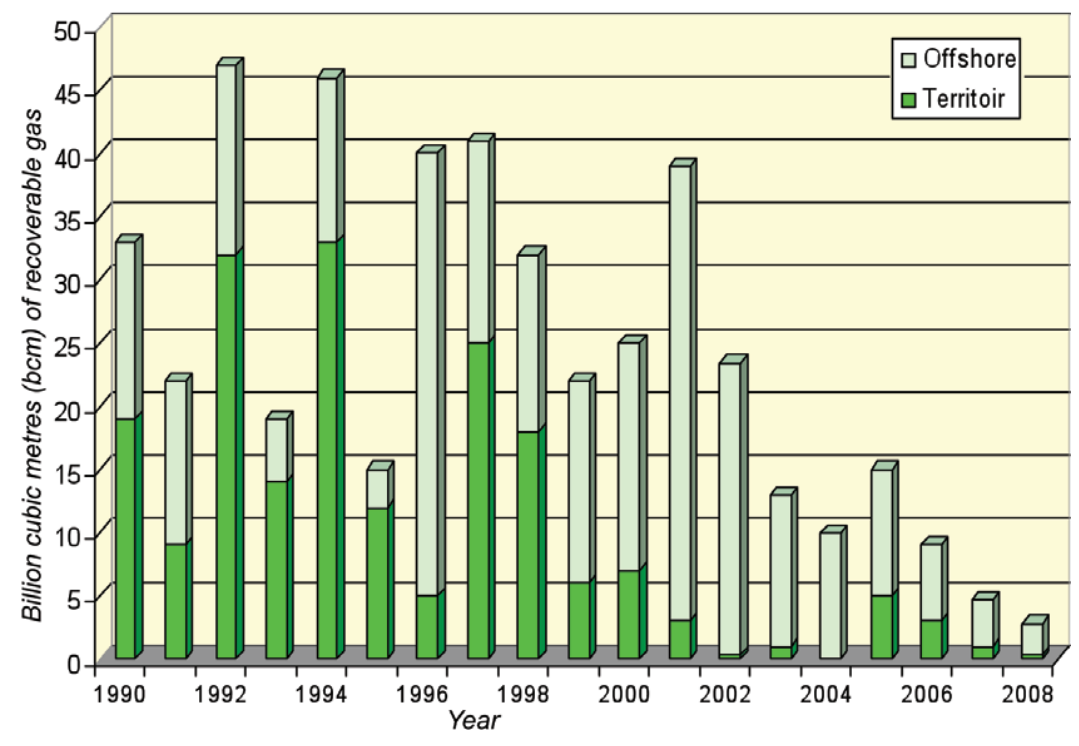



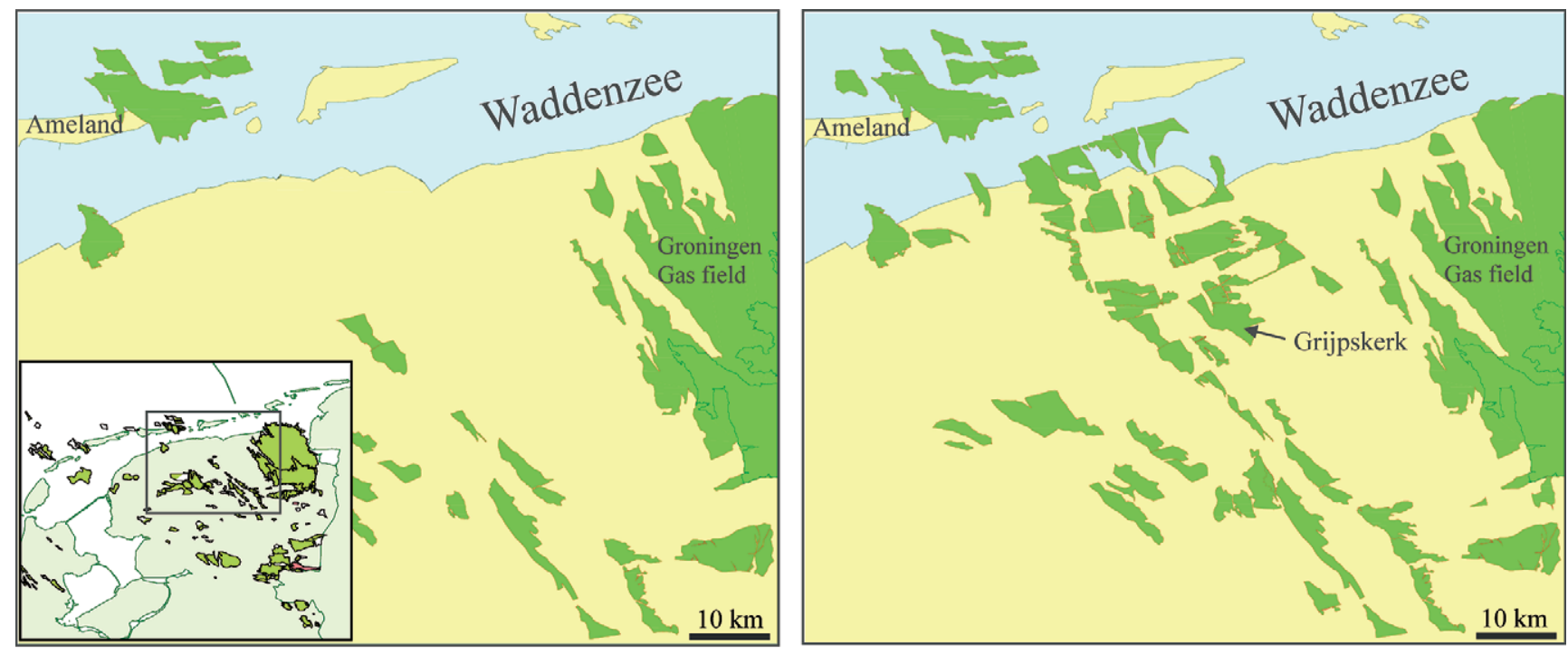

a.

b.

Fig. 3. a. Gas fields in the wider Lauwerszee Trough Area in 1988; before the Grijpskerk discovery. In 1988 the wider Lauwerszee area (NE Netherlands) was considered 'mature' with limited remaining exploration potential. The Grijpskerk discovery changed this view. The gas column was 70 metres longer than predicted, leading to the understanding that in the northern sector of the Lauwerszee trough area, where the Ten Boer Member (the upper member of the Rotliegend) is sufficiently shaly, it can be sealing in juxtaposition with the Rotliegend sandstones; $b$. Gas fields in the wider Lauwerszee Trough Area in 2009. An additional 5 tcf of gas has been found since the discovery of the Grijpskerk gas field.

\section{Oil}

The total volume of recoverable oil found to date is 168 million $\mathrm{m}^{3}$ of oil. Most of this is in the Schoonebeek Field, the largest oil field of onshore West Europe. With a cumulative production of 134 million $\mathrm{m}^{3}$, the remaining reserves are 34 million $\mathrm{m}^{3}$ of oil (Ministry of Economic Affairs, 2009). Production from the Dutch sector of Schoonebeek was stopped in 1996 when the water content of every produced barrel of oil had risen to $95 \%$. However, new production technologies and increased oil prices have led NAM in 2007 to undertake redevelopment of the field with the aim to resume production in 2010. Through a combination of steam injection and horizontal wells the recoverable reserves of the Schoonebeek field have increased by $16-20$ million $\mathrm{m}^{3}$ (NAM, 2006).

Most of the remainder of Dutch oil reserves are in the onshore West Netherlands basin, with minor additional volumes in the offshore Broad Fourteens Basin and Dutch Central Graben. No official numbers are published for the yet-to-find oil exploration potential.

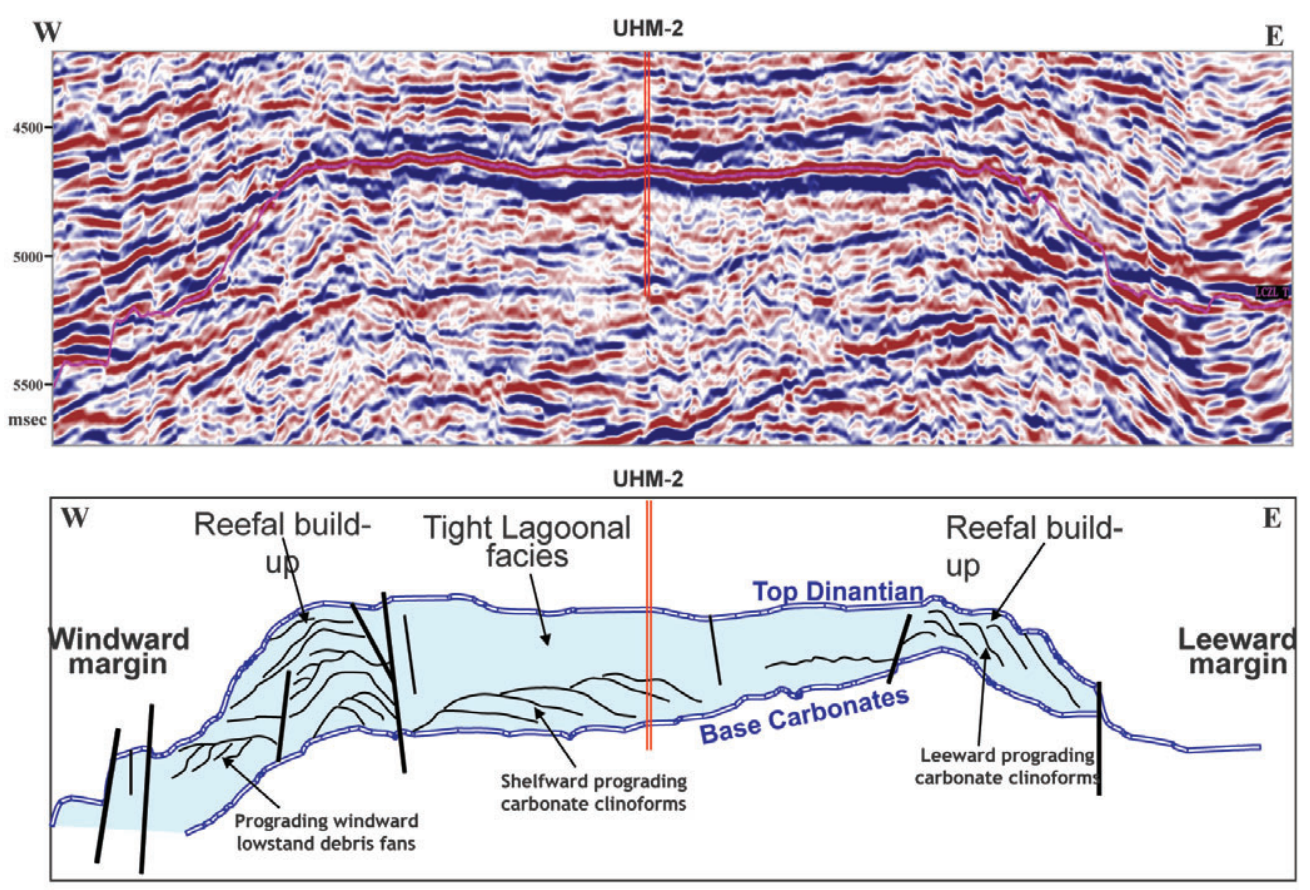

Fig. 4. Seismic and geological cross-section through the Uithuizermeeden-2 well, which reached TD at $5423 \mathrm{~m}$ AHRT in Devonian mudstone. Dinantian carbonates were water-bearing. 
Fig. 5. POS - Success Volume Distribution of prospects in the Dutch inventory of undiscovered conventional exploration potential. From: Bokhoven (2009).

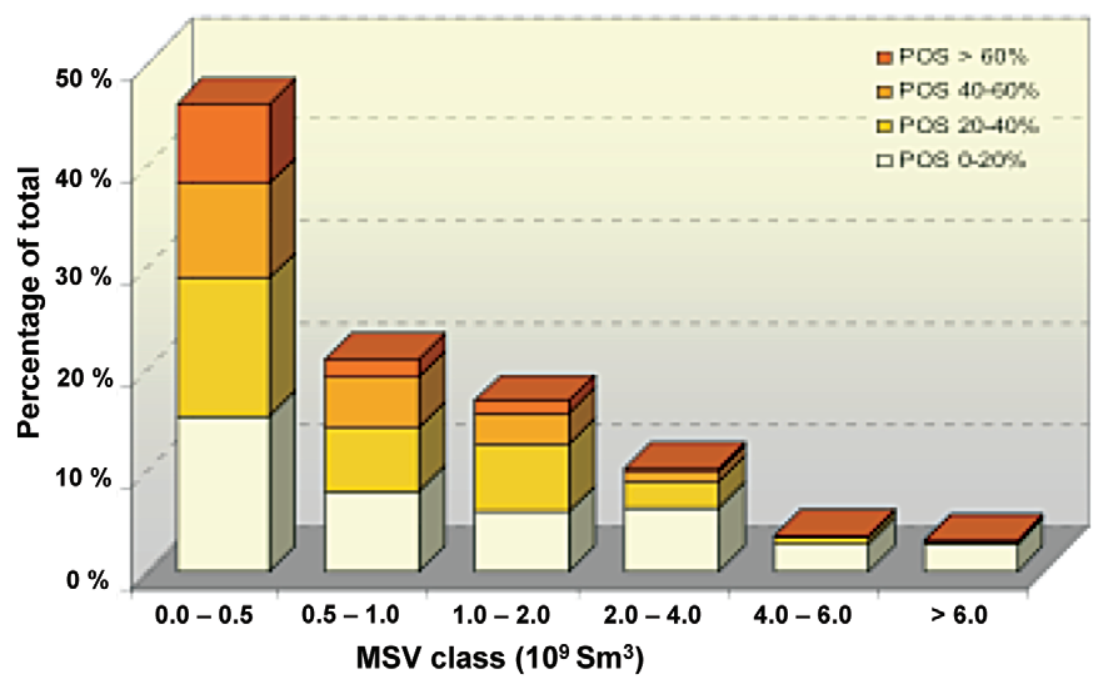

As the field-size of new discoveries gets smaller, the capital expenditure for drilling becomes a larger component of the finding/development cost. In 2003, NAM and Drilltec successfully undertook to modify a pipeline-drilling rig to make it suitable for onshore hydrocarbon drilling to along-hole depths of 5-6 km (Fig. 6). The Drill-Tec Synergy has been in operation since 2005 and within 3 years a 50\% reduction of drilling cost was achieved in comparison with a conventional rig. The small size of the rig also results in a smaller 'footprint' thus enabling a reduction of the size of the drill-site. The rig is now also being used by other operators in the Netherlands and Germany. One of the factors contributing to the success of the Synergy is that the rig specifications have led to a more standardised well design for Rotliegend and Bunter accumulations, yielding considerable cost-savings on materials.

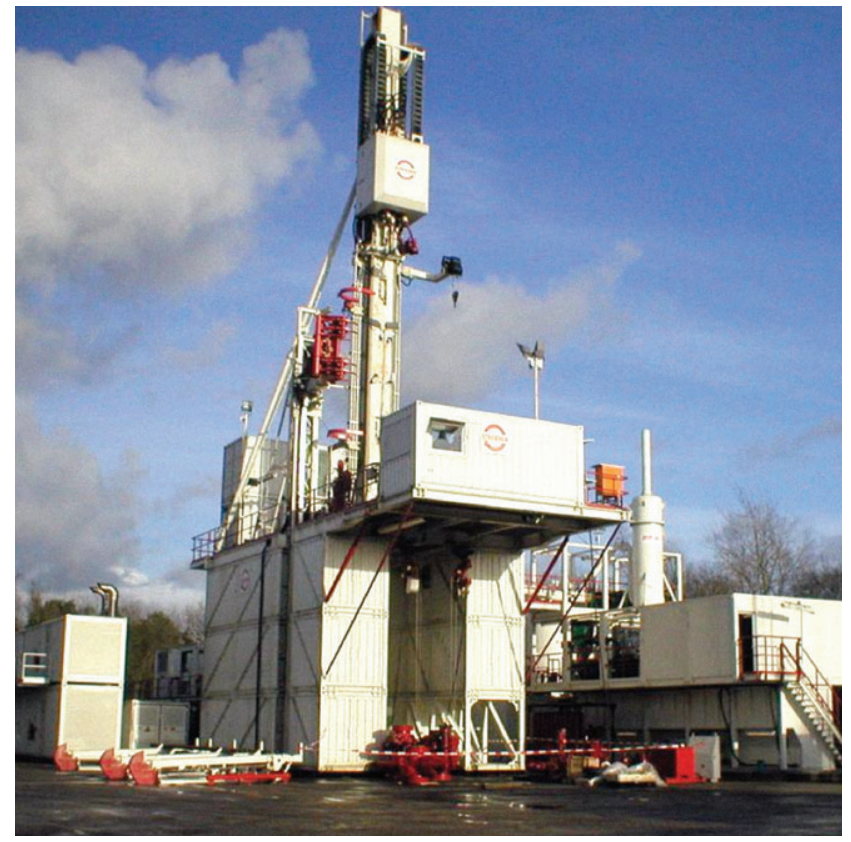

Fig. 6. DrillTec Synergy light land rig. 
In 2008, NAM and Shell UK undertook to apply a similar approach to slim hole drilling offshore by committing to a long-term contract for a light jack-up drilling facility with Swift Drilling NV, a 50/50 joint venture between GDF Suez Energy Services SA and Self Elevating Platforms BV. The rig is currently under construction at Drydocks World's Nanindah yard in Indonesia and is expected to commence operations in 2011 (Fig. 7).

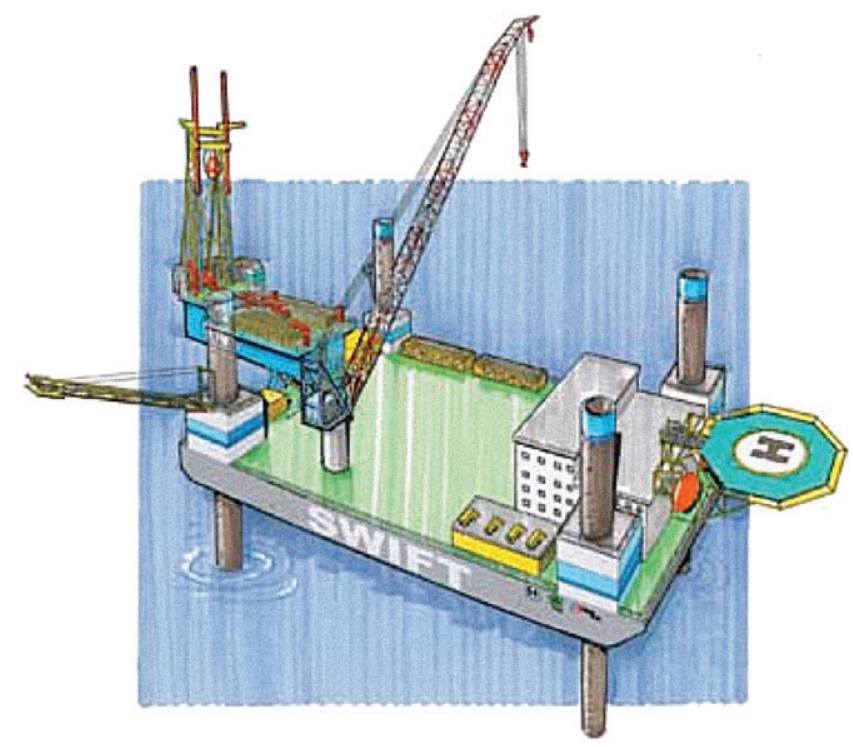

Fig. 7. Light jack-up drilling facility.

Development cost for small fields can be significantly reduced with smaller production facilities, which can also be re-used. An example is the KISS (Keep It Small \& Simple) skidmounted onshore production unit of which NAM has now 14 in operation. Maximum throughput is 1.8 million $\mathrm{m}^{3} /$ day and if larger production capacity is required, several units can be connected in parallel.

Its offshore equivalent is the monotower, based on windmill design. The platform is unmanned without helideck and selfsupporting for its operating energy, which is supplied by solar and wind.

With the above cost reductions and technology, the economic cut-off has been reduced to $0.1 \mathrm{bcm}$ for onshore developments and about $0.5 \mathrm{bcm}$ for offshore satellites.

Notwithstanding all this, the cumulative volume of the discoveries below a commercial cut-off volume is unlikely to exceed a few tens of bcm only, which is not sufficient to change the Dutch gas production forecast significantly.

\section{Tight Reservoirs}

Most of the total volume of stranded gas discoveries is in so-called tight gas discoveries (Ministry of Economic Affairs, 2009). Without a formal definition, the term 'tight gas' is used rather loosely. It describes conventionally trapped gas in reservoirs with low permeability $(<1 \mathrm{mD})$ resulting in subcommercial flowrates per well (typically 1,000-10,000 $\mathrm{m}^{3} /$ day). The tight nature of the reservoirs can be caused by burial-related compaction and by diagenetic processes such as authigenic illite growth in the pore spaces. In many cases, this is accompanied by a high degree of compartimentalisation of the reservoir sequence. Again, technology development plays an important role to unlock this resource.

For economically attractive development, flow-rate and volume-connected-to-the-well are equally important as cost. Hydraulic fracturing of the reservoir around the well-bore is applied more routinely to improve flow-rates in tight formations such as illitised Rotliegend sandstone. An alternative is formed by UnderBalanced Drilling (UBD). Normal drilling practice requires that the drilling mud should have a specific weight, such that the pressure of the column of drilling fluid is higher than the pressure in the aquifers and gas-reservoirs in order to keep the well under control. This is achieved by mixing an appropriate amount of clay minerals, e.g. benthonite, in the mud. However, these clay particles form a so-called 'mudcake' on the borehole wall. This seriously impedes the inflow of gas from low-permeable reservoirs. In UBD, the mudweight is kept intentionally low in order to achieve a controlled flow of gas during drilling of the reservoir section (Fig. 8). With this method, obviously subject to severe safety procedures, considerably improved flowrates have been achieved for instance in the Broad Fourteens Basin. Both fraccing and UBD technology are yielding best results when applied in campaigns of several wells in order to move quickly on the learning curve and to maintain the expertise of the drilling crews. Cooperation between 0perators to build multi-well campaigns is therefore strongly recommended and will also result in reduction of mobilisation cost.

Despite all technology development, flow rates from tight reservoirs will still be on the low side $\left(50,000-100,000 \mathrm{~m}^{3} /\right.$ day), resulting in longer production periods and thus longer pay-out time. Tax incentives allowing early depreciation of development capital expenditure will therefore help to make these reserves more profitable. It should be noted that little exploration has

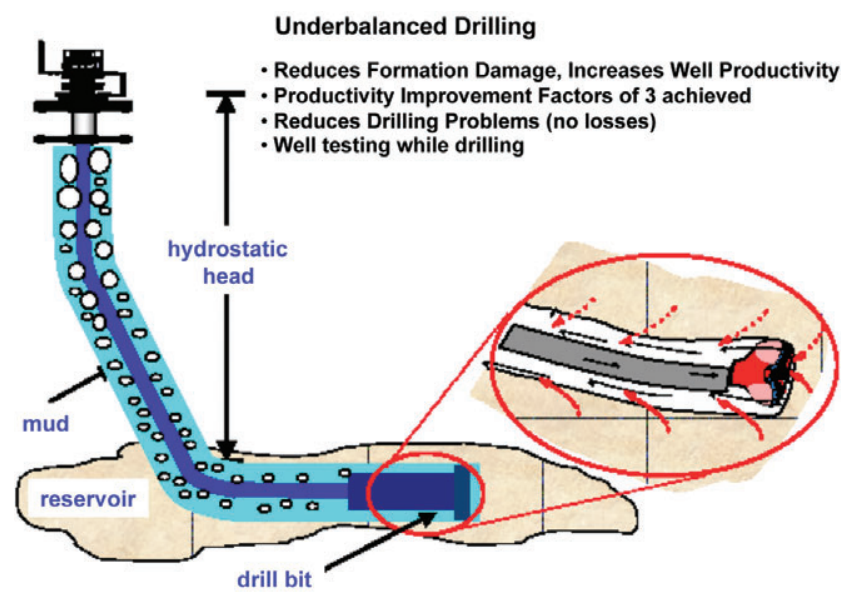

Fig. 8. Schematic representation of UnderBalanced Drilling configuration. 
taken place in areas where reservoir characteristics are known to be challenging. If the development of tight gas discoveries becomes commercial, there is a high likelihood that additional tight gas discoveries can be made.

\section{End-of-Field life}

Whilst not strictly speaking 'stranded', there are volumes of gas left behind in every producing field, when it reaches a point when operational cost exceeds production income. At that time, production is stopped and a decision has to be taken whether to abandon the field or use it for storage. Since the initial development investments can at that moment be treated as sunk cost, there is a strong economic incentive to increase the UR of the field by including as much tail-end gas as possible. Towards the end of the production life of a field the wells run the risk of dying through liquid-loading. With gas flow-rates reducing through reservoir depletion, the water-fraction that invades the borehole can form a column in the tubing. If the hydrostatic pressure of this column exceeds the reservoir pressure the well stops flowing. This process can be temporarily alleviated by injecting foam in the well, thereby reducing the weight of the water column which allows the well still to flow at lower reservoir pressure. Recently this technique of 'deliquification' has been applied successfully in several onshore fields, thereby extending the field life for several years and increasing the total ultimate recovery of the portfolio by several bcm. The next step will be to apply deliquification in the offshore, where extension of end-of-field life is of critical importance to sustain the existing infrastructure.

Enhanced Gas Recovery (EGR) is another promising technique to extend field life. Here, downdip injection of nitrogen or $\mathrm{CO}_{2}$ is aimed at sweeping the remaining gas in pressure-depleted fields or in compartments with residual gas saturations (20$40 \%$ ) to up-dip producers. NAM has carried out some successful field tests of this method using nitrogen in the Dongen Tuffite reservoir in De Wijk and is planning a larger scale EGR project in 2011.

\section{Conventional exploration potential}

As mentioned earlier, the estimates for the undiscovered hydrocarbon potential have a rather wide range and the undrilled portfolio of prospects contains a variety of opportunities. Most are small and many larger ones are carrying a high risk of failure because the exploration play is unproven or uncertainty exists in prospect definition (charge, reservoir, seal, trap).

The economic decision to drill an exploration well is made on the basis of the Expected Monetary Value (EMV), which is defined as:

$$
\mathrm{EMV}=\mathrm{POS} * \mathrm{NPV}-\text { Cost-of-Well } *(1-\mathrm{POS})
$$

where POS is probability of success, NPV is Net-Present-Value of the success case and the cost of well is calculated post-tax.

For a decision to drill, the EMV should at least be $>0$ and the opportunity ranks more attractively if the risk is low, the NPV (largely correlating with volume) is high and the well costs are low. Lowering the well cost improves the economics but does not affect geological risk. Therefore tax incentives should aim at reducing development cost of the success case and not make the net exploration drilling cost cheaper, since that will not improve the overall success ratio of the industry. Geological de-risking is achieved by making use of all existing data and developing and applying technology.

\section{De-risking}

The Near Field Exploration (NFE) portfolio in the Netherlands is dominated by Triassic and Rotliegend prospects close to existing infrastructure onshore and offshore. These small volumes generally require a high POS to be profitable and a reliable estimate of the down-side (P90) volume. A good example of a de-risking technique for POS and determination of success volume of NFE prospects is CTD (Common Top-reservoir Depth) stacking of seismic data (Fig. 9). It has been long recognised that under favourable conditions (high signal-to-noise ratio,
Wedge model

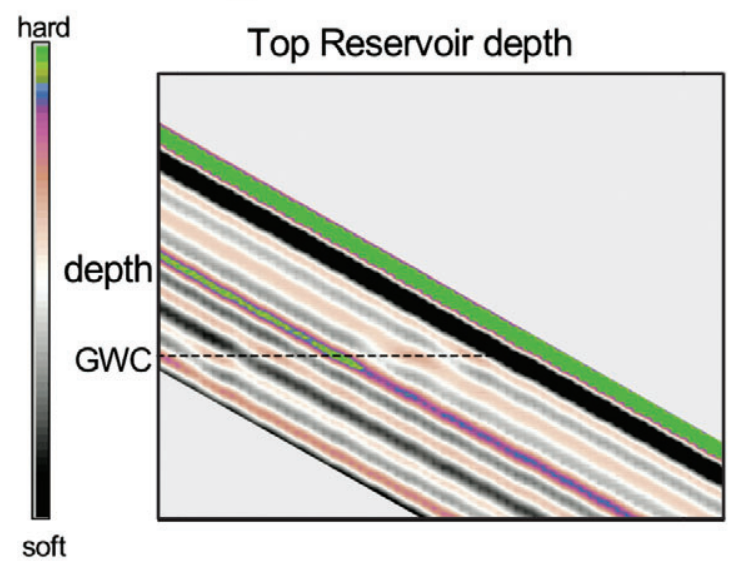

\section{CTD stack}

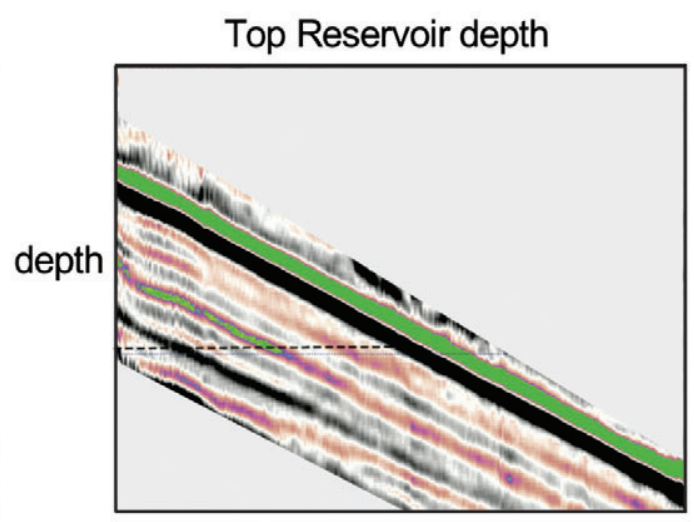

Fig. 9. The Common Topreservoir-depth display provides a very good similarity with a wedge model of the seismic response of a dipping reservoir with a given gas-water contact. 
high porosity) gas-filled reservoirs can be directly discriminated from water-bearing reservoirs on seismic data. These Direct Hydrocarbon Indicators (DHI) have been successfully used in the Netherlands in Triassic (Volpriehausen and Bunter Sst), Lower Cretaceous (Vlieland Sst) and Tertiary (Dongen Tuffite and Miocene sands) objective intervals. With the improvement of 3D seismic data-quality (long offsets, pre-stack depth migration) it has now also become feasible to detect DHI's in structurally complex areas and heterogeneous reservoirs, notably the Rotliegend objective. Especially the CTD stacking method has yielded remarkable results (Bruehl et al, 2008). In this process, all seismic traces from a depth-migrated volume, pertaining to a common top-reservoir depth within a faultblock, are stacked and plotted as a function of depth. This provides a one-to-one comparison with a wedge model of the seismic response of a dipping reservoir with a given gas-watercontact. The CTD stack enhances both depth-conformable events (eg flat spots) and structurally conformable features (e.g. amplitude brightening) whilst suppressing non-parallel shot-generated noise such as multiples.

Application of CTD stacks thus allows a 'POS-polarisation' of the prospect portfolio and provides at the same time a reliable estimate of the gas-water-contact and hence the volume.

Whilst DHI techniques such as CTD stacking are mostly applied in the exploration phase, the de-risking of infill-drilling or stimulation campaigns in the production phase require a combination of disciplines. For instance combining reservoir engineering, 4D (or time-lapse) seismic acquisition and broadband seismic inversion allows in principle the estimation of reservoir permeability from seismic, which has been an enigma for many years. Similarly, good success has been obtained by applying 3-component seismic data to determine fracture orientation by measuring polarisation of wavefields. This information is used to determine optimum orientation of horizontal wells (Van der Kolk et al, 2001).

\section{Remaining conventional exploration potential}

Earlier we have indicated that the potential of new play concepts for providing much additional volume potential must be considered to be limited. Fault-dip closures form the predominant trapping mode for gas fields in the Netherlands and with the abundant coverage of 3D seismic the majority of such closures have been identified and tested by the drill. In a number of discoveries in the Rotliegend however, the gascolumn is longer than can be explained by the mapped spill point of the structure (Fig. 10; De Jager \& Geluk, 2007). It has been demonstrated, also through pressure analysis and gastyping, that this is caused by the sealing capacity of one or more of the boundary faults, preventing the structure to leak through sand/sand juxtaposition. Most remaining potential is therefore considered to be in prospects that may have a GWC deeper than the normal spill point, and that require sealing faults. Detailed mapping, tectonic reconstruction, diagenetic categorisation, gas composition analysis and pressure cell identification allow a prediction of the sealing capacity of faults/fault families. This can unlock a portfolio of exploration targets in newly identified structures with most remaining potential probably in the offshore, as onshore this concept has already extensively been tested, in particular in and around the Lauwerszee Trough.

Next to fault-seal concepts, some examples of unproven plays are deep Jurassic oil in the offshore, highly overpressured deep $(>5 \mathrm{~km}$ ) gas in the Permian Rotliegend and stratigraphically trapped gas in the Carboniferous. However, the volume potential of these in proven plays is also not likely to be very significant.

\section{Unconventional exploration potential}

Unconventional hydrocarbon resources are not limited to conventional structural or stratigraphic traps. They are of
Fig. 10. Evidence of effective fault-seal in sand/sand juxtaposition in Rotliegend fields in NE Netherlands.

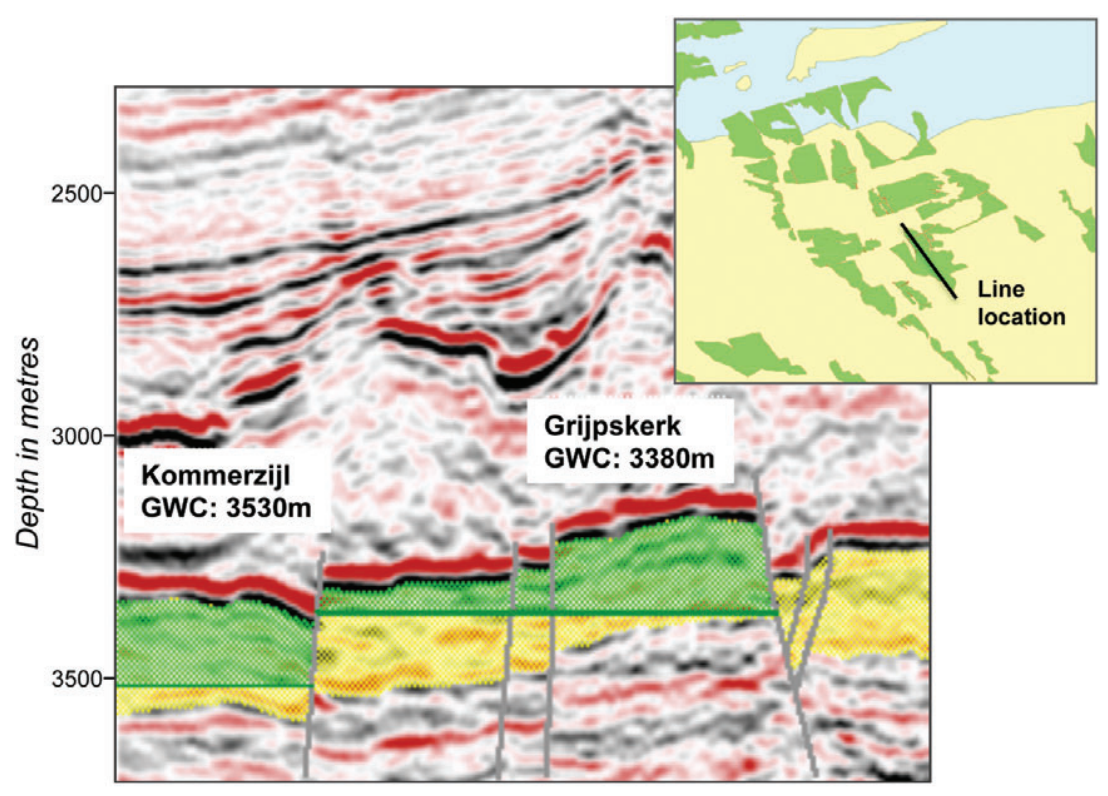


regional or sub-regional extent and, contrary to conventional buoyancy-driven traps, they do not have well-defined hydrocarbon-water contacts. They occur in low matrix-permeability reservoirs $(<1 \mathrm{mD})$ that produce at low rates and therefore require large numbers of wells to develop. The main types relevant for the Netherlands are Basin Centred Gas (BCG) systems, Coal Bed Methane (CBM) systems and Shale Gas systems (Fig. 11). For all unconventional gas resources, when technically proven, commercial production is the main concern. Initial flow rates and total recoverable gas (EUR: Expected Ultimate Recovery) per well need to be sufficient and in balance with drilling, completion and surface facility costs, and with gas prices. All current commercial developments - mainly in the United States of America - are onshore. The costs and scale of offshore development are prohibitive, and this is very unlikely to change, even in the longer-term future. Therefore, in the following only the onshore potential of unconventional resources is considered.

\section{Basin Centred Gas}

Basin Centred Gas (BCG) systems are regionally pervasive gas accumulations in tight clastics with no apparent structural or stratigraphic trapping configuration. Close interbedding with prolific source rocks (generally coals) is an important prerequisite. The first well-documented case of BCG was the description of the Deep Basin Gas Trap in Western Canada by Masters (1979). In general, BCG systems are abnormally pressured (high or low), lack a downdip gas-water contact and have low average permeability reservoirs (<0.1mD) (Law, 2002). Sweetspots with higher than average permeabilities and porosities do occur and are often critically important for commercial development. In the USA and Canada there are many established BCG systems with a long production histories, for example: Alberta Basin Canada (Master, 1979, 1984), Greater Green River Basin (Law 1984, 2002), Piceance Basin (Hood \& Yurewics, 2008; Yurewicz et al., 2008), San Juan Basin (Huffman, 1996).
BCG systems have several characteristics in common. In addition to pervasive gas saturations without structural control and generally poor reservoir, they do not produce water (or only in small amounts), generally occur in settings with coals in proximity to the reservoirs and productive BCG systems generally have been buried rapidly and experienced a phase of late uplift and exhumation (Table 1).

The development of BCG systems has been described in 4 phases (Law, 2002).

Phase 1: Burial and compaction of the reservoir.

Phase 2: Further burial and prolific gas generation from intercalated source rocks (e.g. coals). Because of the tight nature of the reservoir rocks, gas accumulates in the reservoir faster than the rate at which gas is lost. As gas accumulates in the pore space, the capillary pressure of the initially waterwet pores is exceeded and mobile water is expelled resulting in an overpressured system with very little water.

Phase 3: Uplift and erosion. This will cause trapped gas to expand, gas dissolved in formation water to come out of solution, and fractures to develop and/or open. Over time, gas leakage through these newly developed fractures may result in an underpressured BCG system.

Phase 4: Continued gas loss may cause water to re-enter the underpressured reservoir and a general decay of the BCG system, and eventually a return to conventional conditions.

The trapping mechanism is not fully understood, but the generally accepted view is that trapping involves the concept of a relative permeability or water block seal, often referred to as a capillary pressure seal. This can occur in low permeability reservoirs in which the relative permeabilities of gas and water do not overlap for any saturation value, resulting in a gas 'permeability jail'. From Figure 12, it can be seen that in order to be able to produce gas, gas saturations must be higher than

Fig. 11. Schematic cross-section showing various types of conventional and unconventional trapping modes. From Pollastro et al. (2003).

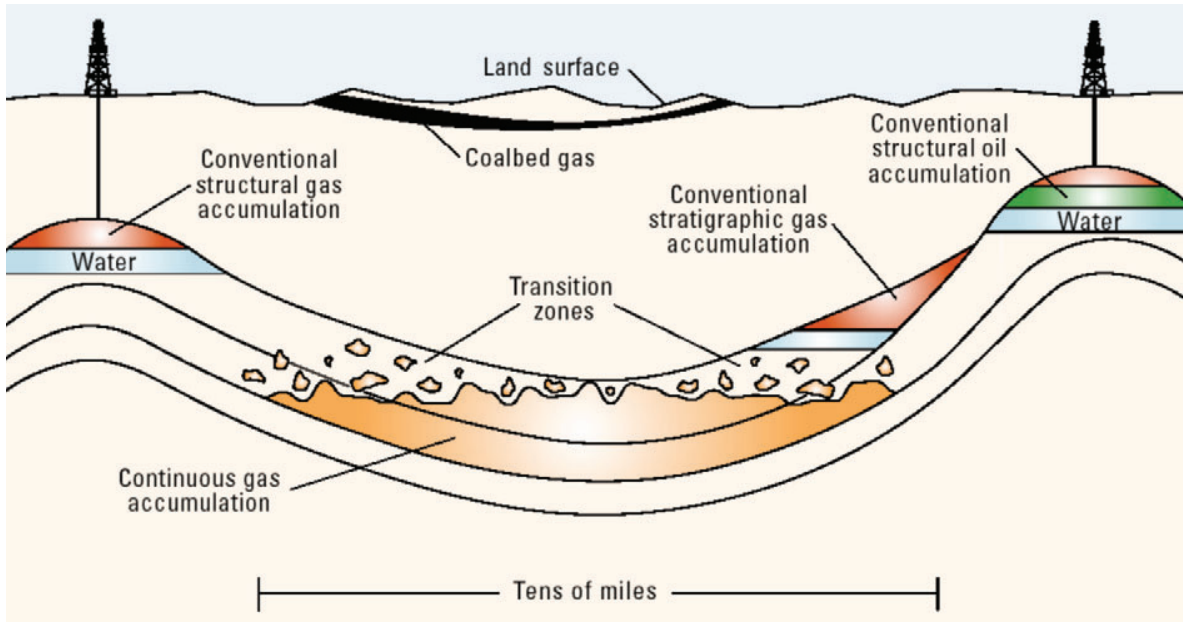


Table 1. Favourable conditions for development of unconventional gas resources

\begin{tabular}{|c|c|c|}
\hline Basin Centred Gas & Shale Gas & Coal Bed Methane \\
\hline $\begin{array}{l}\text { Reservoirs with low porosity }(5-10 \%) \text { and low average } \\
\text { permeability ( }<1 \mathrm{mD} \text {, often less then } 0.1 \mathrm{mD})\end{array}$ & $\begin{array}{l}\text { Source rock with relatively high TOC, } \\
\text { generally at least } 2 \%\end{array}$ & $\begin{array}{l}\text { Less than } 1000-1500 \mathrm{~m} \\
\text { below surface }\end{array}$ \\
\hline Associated with (intercalated) prolific gas mature source rock (coal) & Thick; at least $30 \mathrm{~m}$, preferably $>50 \mathrm{~m}$ & $\begin{array}{l}\text { Coal beds thicker than } 2 \mathrm{~m} \\
\text { (or multiple beds of }>1 \mathrm{~m} \text { ) }\end{array}$ \\
\hline Regionally pervasive gas saturation & Gas Mature: Ro>1.2 \% & Gas mature: Ro $>1.0 \%$ \\
\hline Well tests with very little to no water production & $\begin{array}{l}\text { Porosity in the } 3-8 \% \text { range and } \\
\text { typically nano-Darcy permeability }\end{array}$ & \\
\hline Abnormal pressures (under- or over pressure) & $\begin{array}{l}\text { Composition supporting development } \\
\text { of fractures (silica, carbonate content) }\end{array}$ & \\
\hline Late uplift and exhumation & Late uplift and exhumation & \\
\hline
\end{tabular}

$60 \%$; with lower gas saturations the relative permeability for gas in these tight reservoirs is zero. The tighter the reservoir, the higher the gas saturations must be to exceed the critical gas saturation above which the relative permeability of gas is more than zero. Masters (1979) defined a minimum Bulk Volume Water number of 0.045 (BVW = porosity * gas saturation) required for producible gas. This implies that for gas saturations of $80 \%$ porosities must be higher than $5.6 \%$, and if gas saturations are only $60 \%$ porosities must be more than $7.5 \%$.

For BCG systems to develop it is essential that gas enters the reservoir when the rock is already tight, but not so tight that gas cannot enter anymore. Late tectonic uplift is an important ingredient for 'drying' the system by gas expansion and chasing out any remaining free water. In addition, uplift may produce fractures, or open existing ones, allowing higher, potentially commercial, production rates. BCG accumulations often comprise multiple, stacked reservoirs of hundreds and sometimes up to several thousands of metres thick. Commerciality of BCG developments is a very serious concern in most cases. Normally only a fraction of the total BCG system will be productive. Productive 'sweetspots' may result from presence of fractures or local better reservoir characteristics, and can also be related to favourable surface conditions. In practice, our geological models and geophysical analyses are in most cases of insufficient detail to allow prediction of which wells will be commercial and which ones not. Unconventional plays can therefore be referred to as 'statistical plays'; the average development well in a sweet spot area needs to be commercial, with a few exceptional producers paying for a potentially larger proportion of subcommercial producers. Development of BCG accumulations requires very dense drilling. Spacing of development wells is typically in the range of 100 's of metres. Obviously, the environmental impact of a BCG development can be enormous. To give an indication of the volumetric potential of BCG developments, the total potential of the San Juan Basin is reported to be some $500 \mathrm{bcm}$ in-place gas (U.S. Geological Survey, 2002).

In the Netherlands the thick Westphalian is the most obvious stratigraphic interval where BCG systems may have developed, as it has several favourable characteristics in common with known successful BCG systems. It has been deposited in a rapidly subsiding foreland setting, has rather tight reservoirs
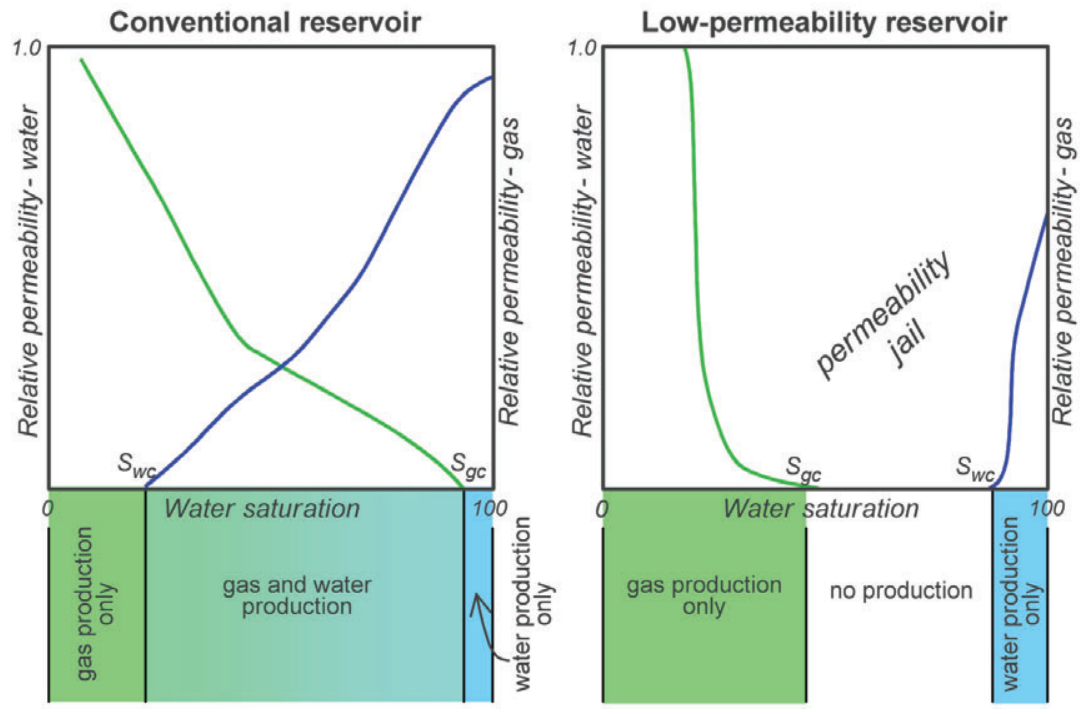

Fig. 12. In conventional reservoirs there is a large overlap of the relative permeability curves for gas and water resulting in a wide range of water saturations where both gas and water can flow. In tight lowpermeability reservoirs there is a wide range where neither gas nor water can flow. This is referred to as the 'permeability jail'. Swc and Sgc are the critical saturations for water and gas respectively, below which the relative permeability of water and gas are zero. After Shanley et al. (2004). 
where it has been deeply buried, it contains intercalated coals, it can be overpressured and has experienced late (Early Tertiary) uplift in inverted areas such as the West and Central Netherlands Basins and in Twente and the Achterhoek in the East of the country (Fig. 13). In these inverted areas the top of the Westphalian is everywhere shallower than $3000 \mathrm{~m}$, and in many places shallower than $2000 \mathrm{~m}$ (Fig. 14, from Van Buggenum \& Den Hartog Jager, 2007). However, there are many examples of water tests from intra-Westphalian levels throughout the Netherlands, and in existing deeper wells such as Winterswijk and Tjuchem no pervasive high gas saturations have been evaluated, suggesting that no BCG system is present there. This may be explained by some differences between a potential Dutch Westphalian BCG system and North American proven and commercially developable BCG systems:

1. The Westphalian has been subject to several periods of uplift (Carboniferous-Permian, Jurassic and Late Cretaceous - Early Tertiary), whereas the American BCG systems have been uplifted just once.

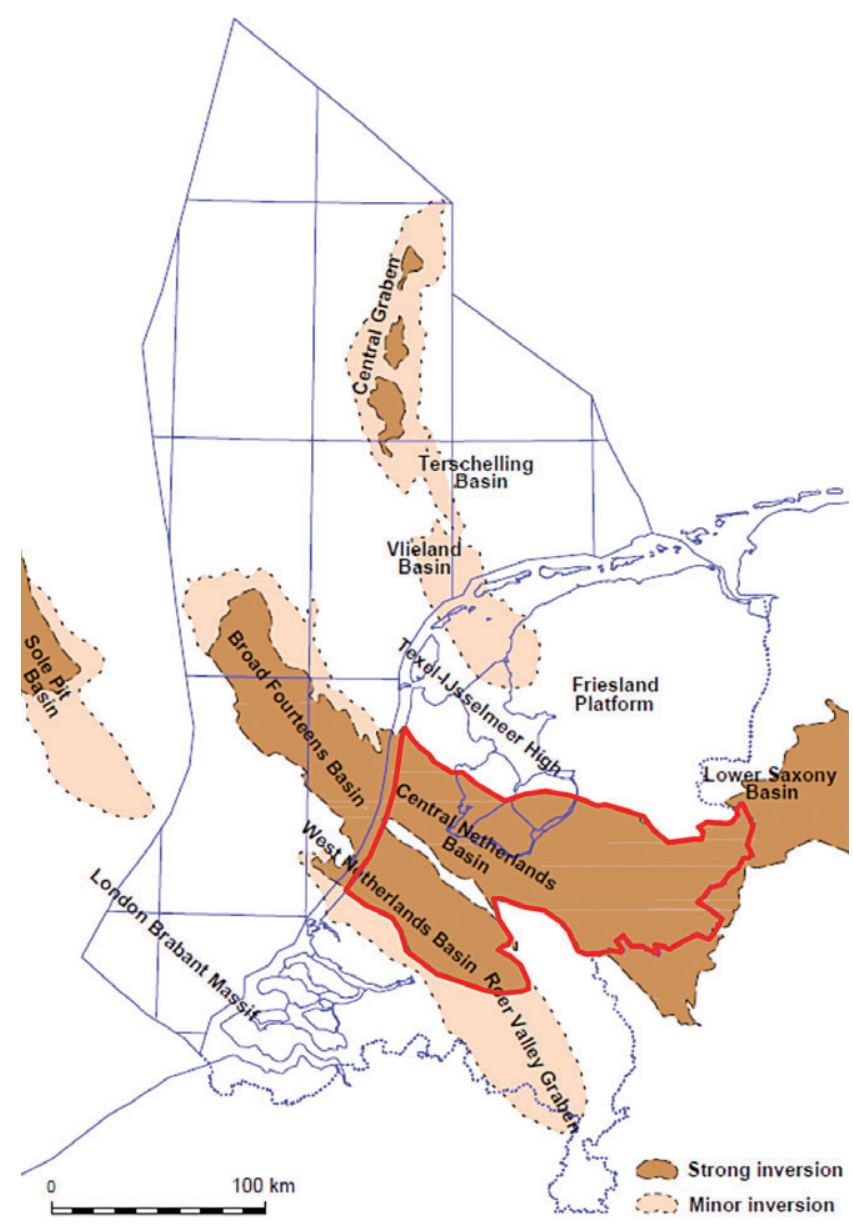

Fig. 13. Inverted areas in the Netherlands. Light shading shows mildly inverted areas, where the Upper Cretaceous is thin as a result of erosion and/or limited deposition; dark shading shows strongly inverted areas where no chalk has been preserved. The area within the red line is the strongly inverted sector of the Dutch onshore. From: De Jager (2003).

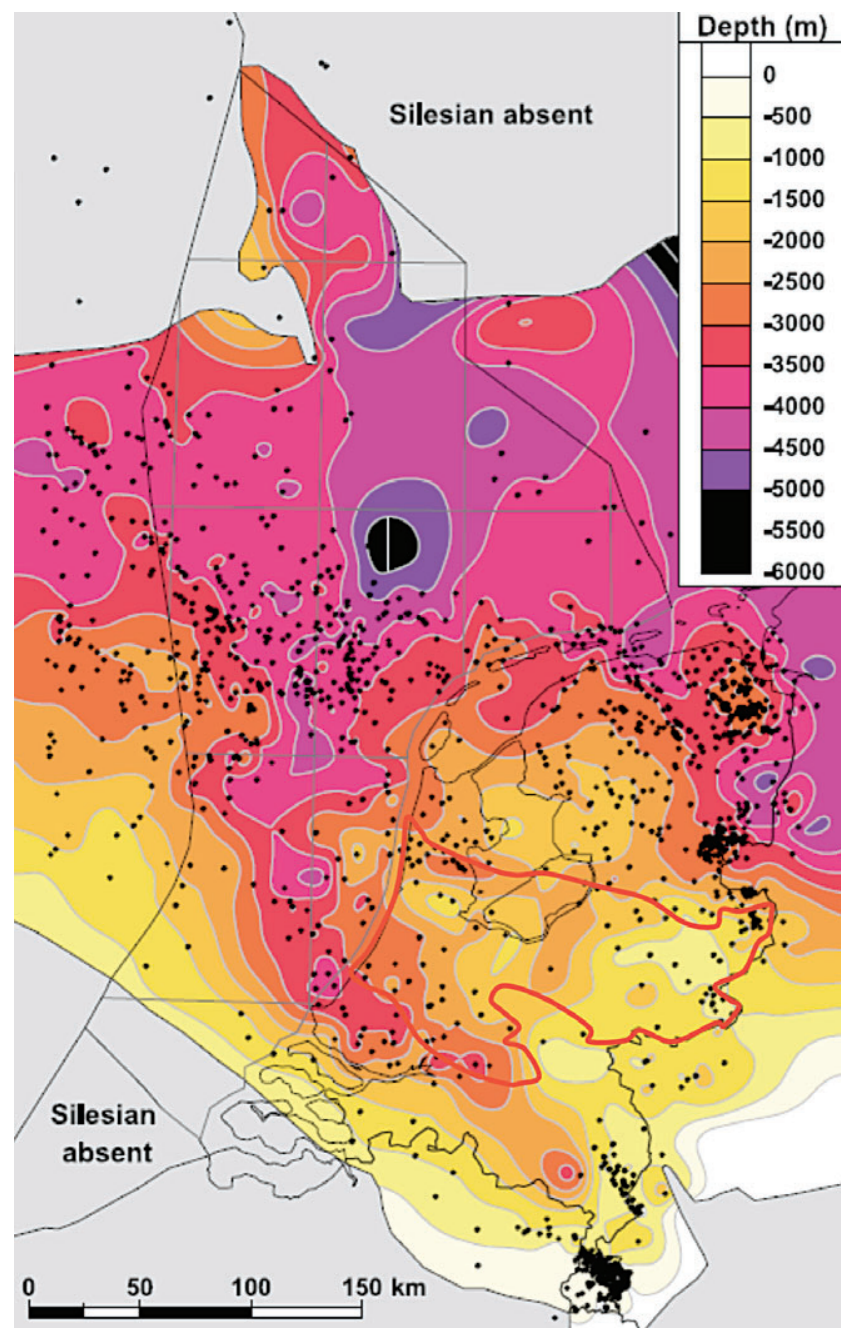

Fig. 14. Depth to top Carboniferous; from: Van Buggenum and Den Hartog Jager (2007). The area within the red line is the strongly inverted sector of the Dutch onshore (compare with Fig. 9).

2. The late uplift in the North American basins is generally more recent than in the Netherlands: Miocene in North America, versus Paleocene for the Lower Saxony Basin and at the Eocene-Oligocene boundary for the West and Central Netherlands Basins. BCG systems where uplift occurred too long ago may have started to decay resulting in an ineffective BCG system with higher water saturations and lower initial well productivities.

If a BCG system can be proven in the Westphalian, the area that could reasonably be expected to be commercially developed will be significantly smaller than the entire area indicated in Figures 13 and 14, as productive 'sweet spots' always only represent a fraction of the total play area. Secondly, in the Netherlands, inaccessibility of densely populated areas and nature reserves (e.g. cities and the National Park The Veluwe) is an important surface factor limiting exploitation.

A second stratigraphic interval in which a BCG system could have developed is the Upper Jurassic Delfland Group. This Group 
does not occur everywhere, and the only onshore area where a BCG system could have developed is in down-faulted areas of the West Netherlands Basin (Fig. 15). To date, most exploration drilling occurred on structural highs, and the petrophysical characteristics of the more deeply buried Delfland Subgroup in the main halfgrabens are not well calibrated. However, the sequence has been buried less deep than the Westphalian and limited burial-related compaction and diagenesis may not have been enough for a sufficiently tight BCG system to develop. In addition, the quantity of intercalated coals is much less than in the Westphalian and in large areas their maturity will be insufficient $($ Ro $<1.0)$ to have generated and expelled sufficient amounts of gas for pervasive gas saturations. Based on these considerations it is rather unlikely that the Delfland Group represents a BCG system.

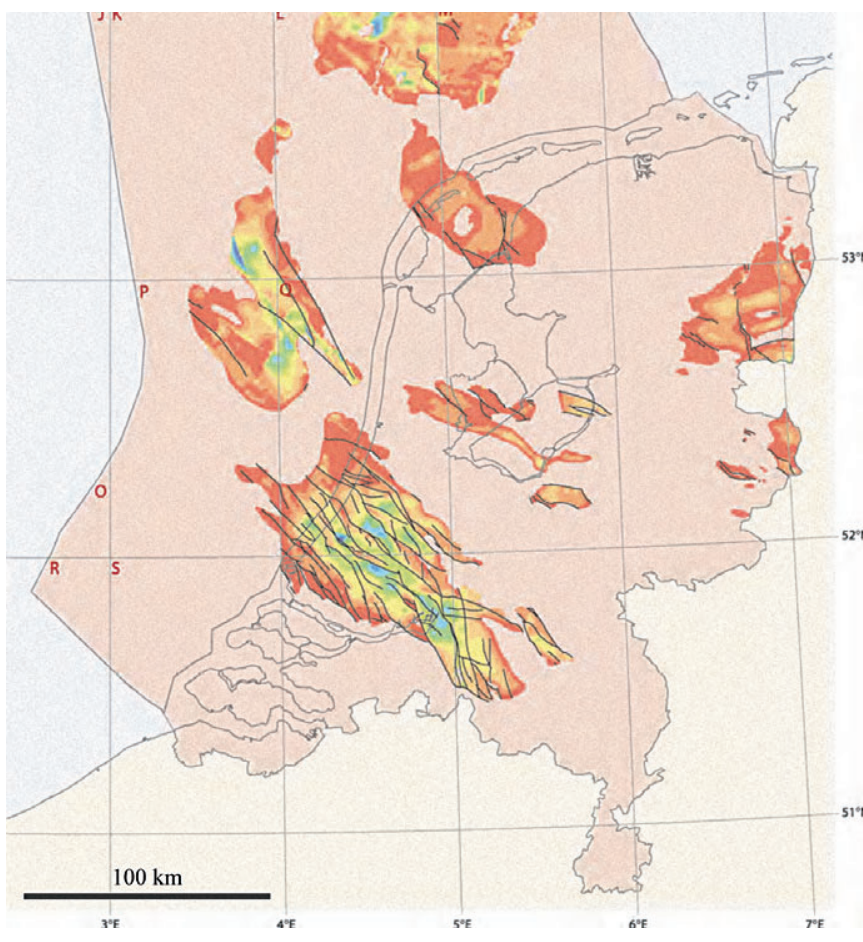

Fig. 15. The isopach map of the Upper Jurassic (from: Wong, 2007) indicates that the Upper Jurassic is present only locally in the subsurface of the Dutch onshore, with the thickest development in the West Netherlands Basin. The distribution of the Delfland Group is somewhat smaller than that of the entire Upper Jurassic.

When estimating a realistic volume for the exploration potential for BCG, the following parameters need to be taken into account:

1. The top of a potential BCG system. By inference, this must be deeper than the top of the Westphalian, since in no wells where the Westphalian has been encountered to date, a BCG system with pervasive free gas has been identified.

2. In order to achieve some materiality, a sufficient thickness of Westphalian must be developed as a BCG system above a commercial floor, determined by well costs and potential flow rates. An assessment of a commercial floor for BCG development requires an economic analysis, but this is unlikely to be much deeper than $4 \mathrm{~km}$.

3. Development of BCG is normally only commercial in socalled sweet spots, which cover only a fraction of the total area where a BCG system may be present.

4. The sweet spots must be accessible, and environmentally sensitive areas and densely populated areas must be excluded.

Based on the considerations above, we estimate that if a BCG system can be proven in the deep Westphalian of the Netherlands, total unrisked recoverable volumes would not exceed several 10's of bcm of gas. In addition, there is a high risk that no commercial flow rates and EUR volumes can be achieved.

\section{Shale Gas}

Shale Gas (SG) systems are found in organic rich shales (Curtis, 2002), which form both source rock and reservoir, sealed by capillary seals similar to BCG systems. Gas is present both as free gas in (micro)pores and fractures, and as sorbed gas on kerogen and pyrobitumen. Petrophysical evaluation of SG systems is notoriously difficult, typically resulting in very large uncertainty ranges for reservoir parameters and gas saturations. Given the extremely low shale matrix permeability, the presence of fractures (natural or induced) is essential for commercial production rates, and productive shale gas formations generally have a mineralogical composition that facilitates development of natural or induced fractures, such as silica or carbonate. The first commercial SG development dates from as long ago as 1821 (Curtis, 2002). Currently there are several commercial SG developments in the USA, responsible for $7 \%$ of the total domestic gas production (Curtis, 2009). To date most production has come from the Ohio Shale of the Appalachian basin and the Antrim Shale of the Michigan Basin. Other developments are in the New Albany Shale of the Illinois Basin, the Barnett Shale of the Fort Worth basin and the Lewis Shale of the Central Juan Basin (Curtis, 2002). Production from the Barnett Shale is increasing and has evolved into one of the best-known shalegas resource plays (Jarvie et al, 2007). The Barnett Shale occurs at depths of generally 2 to $2.5 \mathrm{~km}$, with average thickness of about circa $100 \mathrm{~m}$ in the core areas. In the last few years the Haynesville Shale in Louisiana has become 'hot' with good initial production rates and correspondingly high prices being paid for land leases. SG developments have in common that they are in high-TOC source rocks. SG wells do normally not flow without stimulation, and hydraulic fraccing is required in all wells.

Characteristics of commercially producing Shale Gas plays are (Table 1):

1. Average TOC values of more than 2 or $3 \%$, the only exception being the Lewis Shale.

2. Minimum thickness of several 10 s of metres, required for horizontal development wells. 
3. Maturity in the gas window: i.e. Ro>1.2 for Type II source rocks.

4. A mineralogical composition supporting development of fractures (silica, carbonate).

5. Late uplift, to bring the unit within drillable depth and to create or open fractures.

Both thermogenic and biogenic gas can occur in SG reservoirs, with biogenic gas predominant in the Michigan and Illinois basin plays. In the Netherlands potential Oil Shales occur too deep for biogenic gas generation, and only thermogenic gas can be expected when maturities are sufficiently high ( $\mathrm{R} 0>1.2)$.

The best known oil shale in the Netherlands is the Jurassic Posidonia shale, with a gross thickness of 15 to locally $35 \mathrm{~m}$ and an average TOC of $10 \%$ with a $\mathrm{HI}$ of 800 . As an oil prone source rock it needs to be buried sufficiently deep to represent a viable SG resource. Onshore, in the West Netherlands Basin and Roer Valley Graben, this source rock only reached gas maturity in small and isolated synclines in the deepest part of the basin (De Jager et al, 1996). Elsewhere there are some other onshore occurrences of the Posidonia Shale, such as locally below the IJsselmeer polders in the NE of the country, but these are of insufficient extent to be considered potentially commercial.

The second potential SG resource could be the Namurian marine source rock unit of the Geverik Member. In the well Geverik-1 situated to the south of the southeastern part of the Roer Valley Graben, a Type II source rock has been penetrated in the basal, marine Namurian (Geverik Member). The source rock has a high TOC (8\%) (Van Balen et al, 2000), but a total thickness of only $15-25 \mathrm{~m}$, which is on the lower end of what is considered to be the minimum for a commercial SG play (Curtis, 2002). Elsewhere in the Southern Permian Basin the equivalent of this Namurian source rock is known as well, for example the Boland Shale in the UK, and it is generally thought that it occurs under much of the Netherlands. Only in a relatively narrow band just north of the London-Brabant Massif may this unit be sufficiently shallow to be considered a potentially commercially producible SG resource. In the Netherlands, there are only a few penetrations of this Namurian source rock, and its regional presence and source rock potential along its southern basin margin is poorly calibrated. Contrary to some views, it may not be omnipresent: the 018-01 and S2-2 wells, located not far north of the London Brabant Massif, reached to Silurian units, did not encounter source rocks in the lower part of the Carboniferous (fig. 2.10 of Kombrink, 2008). No detailed maturity maps have been published for this unit, but even if it contains source rock, it is probably well in the gas window, or even overmature, over very large areas.

The well-known Kimmeridge Shale, the prolific source rock in much of the central and Northern North Sea, looses its source rock potential towards the south, and is not considered a source rock anywhere in the Dutch subsurface. Consequently, this unit does not represent a viable SG source for the Netherlands.
Other source rock intervals are either too thin (e.g. Coppershale) or have insufficient average TOC (e.g. Epen Fm, Aalburg). These last formations may have isolated streaks with high TOC values, but for a commercially productive SG resource intervals of several $10 \mathrm{~s}$ of metres with average TOC values of at least $1.5 \%$ are required.

Based on above considerations we are of the oinion that the SG potential in the Netherlands is limited to the extreme south of the country (Peel area). The Namurian Geverik Shale could present a viable SG resource, even though its distribution and extent along the southern basin margin of the Lower Carboniferous basin is poorly constrained and that the thickness of this source rock appears on the low side of known commercial ventures. In view of all uncertainties associated with the Geverik Shale as potential SG resource a reliable quantification of its potential is considered premature, but we do not expect this to exceed 10-20 bcm.

Industry interest in SG plays in Europe has risen during the last years with several companies obtaining licences in Germany, UK, Poland and in the Netherlands indeed in the Peel, where in 2009 an exploration license has been awarded, indicating some industry interest

\section{Coal Bed Methane}

For Coal Bed Methane (CBM), coal layers are both the source and reservoir for the gas, which is absorbed onto the solid matrix of the coal. The methane is in a near-liquid state, lining the inside of pores within the coal. Gas within the pores and fractures of the matrix represents normally only an insignificant contribution. CBM contains very little heavier hydrocarbons such as propane or butane, no natural gas condensate, and often some carbon dioxide. The coals must have been buried sufficiently deep in order to generate sufficient quantities of gas. Normally maturities of more than $\mathrm{Ro}=1$ are required. The opposing effects of temperature and pressure control the maximum amount of methane that can be adsorbed onto the coal. In general, maximum sorption efficiency occurs at a depth of circa $1500 \mathrm{~m}$ (Van Bergen et al, 2007); i.e. shallower than the maximum burial required for maturities higher than 1 . As coals are highly compressible, there is a strong correlation between permeability and depth of burial. In the USA, essentially all production comes from depths less than $1200 \mathrm{~m}$ (Ayers, 2002). Deeper burial results in lower, and sub-commercial, production rates. Consequently, commercially productive CBM resources are all located in uplifted areas. With the gas confined in the coal matrix, a CBM accumulation can 'survive' significant structural uplift to shallow depths without too much gas leakage. CBM systems may also contain a significant amount of biogenic gas, resulting from influx of meteoric waters at relatively shallow depth, with reservoir temperatures of less than 60 to $70^{\circ} \mathrm{C}$. In the Netherlands, however, water salinities within the Westphalian do not indicate influx of fresh meteoric waters. 
In the USA CBM production is very successful, making up $10 \%$ of the domestic gas production in 2006 (Chakhmakhchev, 2007), in majority (80\%) from the Late Cretaceous Fruitland Formation of the San Juan Basin (Ayers, 2002). Because of variations in reservoir quality, producing fairways or sweet spots comprise less than $10 \%$ of the total area of producing basins (Ayers, 2002).

For production, the reservoir pressure needs to be reduced in order to release the adsorbed gas from the coals. This involves initially production of large amounts of formation water, often for periods of many months that need to be disposed of.

No CBM wells have yet been drilled in the Netherlands; however, the Westphalian sequence has been tested for CBM across the border. In Germany Conoco has drilled some disappointing wells for CBM. And in Belgium, the Peer well was drilled in 1992, which was abandoned because of very high water production and only some methane production, without sufficient reduction of reservoir pressures. The high water production was concluded to be caused by proximity to open faults, and does not condemn better conditions elsewhere. Nevertheless, there have been no further attempts to produce CBM in the Netherlands or Belgium, but recently (2009) two licenses have been awarded for CBM exploration.

In the Netherlands, Westphalian coals represent the only potential CBM resource. In most of the Netherlands the presentday depth of this sequence is far too deep for commercial production. Only in the south-east (province of Limburg), east ('Achterhoek') and South-west ('Peel') of the country is the top of the Westphalian shallower than $1500 \mathrm{~m}$ (Fig. 14). In the Peel.

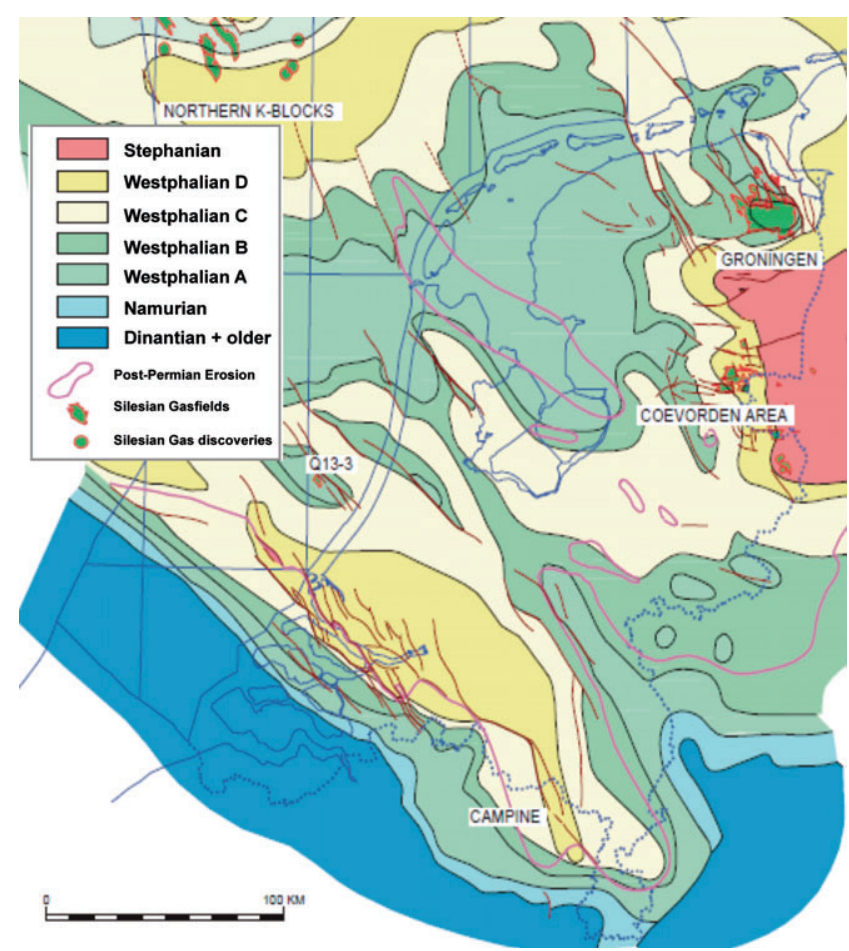

Fig. 16. Subcrop map of the Westphalian at the Base Permian Unconformity. From Van Buggenum \& Den Hartog-Jager (2007).
However, part of the coal-bearing Westphalian A and B has been eroded below the Base Permian Unconformity (Fig. 16). Elsewhere, the coals do not always occur directly at the top of the Carboniferous. In those areas, the top of the Westphalian needs to be even shallower for a potentially viable CBM development.

The CBM resource potential of the Netherlands has been assessed several times. Wolf et al. (1997) estimated that 770 bcm of recoverable gas could be present at depths shallower than $2 \mathrm{~km}$. In 2000, Van Bergen et al came to significantly lower volumes. They concluded that the recoverable volumes shallower than $1.5 \mathrm{~km}$ amount to $32 \mathrm{bcm}$, and significantly more if CBM resources down to $2 \mathrm{~km}$ are included. Partly the same authors write in 2007 (Van Bergen et al, 2007) that the producibility of CBM resources deeper than $1.5 \mathrm{~km}$ is technically and commercially questionable. In a report written in 2009 however, TN0 still quotes a much higher range of 300 $600 \mathrm{bcm}$ of recoverable gas from coals shallower than $2 \mathrm{~km}$ for the onshore, and even somewhat higher volumes if $\mathrm{CO} 2$ injection is assumed which will result in higher recovery efficiencies (Muntendam-Bos et al., 2009).

Based on world-wide experiences with development of CBM, it must be concluded that development of resources deeper than $1.5 \mathrm{~km}$ must be viewed as highly speculative, both technically and commercially. With a more complex tectonic history than commercial CBM ventures in the USA, development of CBM resources in the Netherlands will not be straightforward. In addition, in view of the large volumes of produced formation water that needs to be disposed of, the environmental impact of CBM may even be more severe than that of other unconventional gas resources. Based on these considerations, we do support the first estimate from Van Bergen, and conclude that the Dutch CBM potential is no more than some $30 \mathrm{bcm}$ recoverable gas.

\section{Reduction of surface footprint in unconventional field development}

The Netherlands is very densely populated; hence areas where oil \& gas activities can take place are very limited and are subject to severe permitry (Fig. 17).

For onshore conventional gas, a limited number of production locations with clustered, deviated wells are usually sufficient to properly drain the field. For example, the Groningen gas field has total initially recoverable reserves of $2875 \mathrm{bcm}$ and an areal extent of $860 \mathrm{~km}^{2}$; to date, $2087 \mathrm{bcm}$ is drained from some 296 wells on 29 production locations. On average, this yields a recovery per well of $7 \mathrm{bcm}$, enabled by the excellent Rotliegend reservoir quality. Annerveen, the second largest onshore gasfield with initial recoverable reserves of $70 \mathrm{bcm}$, is drained from 18 wells, yielding a recovery of almost $4 \mathrm{bcm}$ per well. In contrast, modern small fields with UR of $0.5-1.5 \mathrm{bcm}$ are drained by single wells, often with application of mobile production stations which greatly reduces the footprint at the surface. 


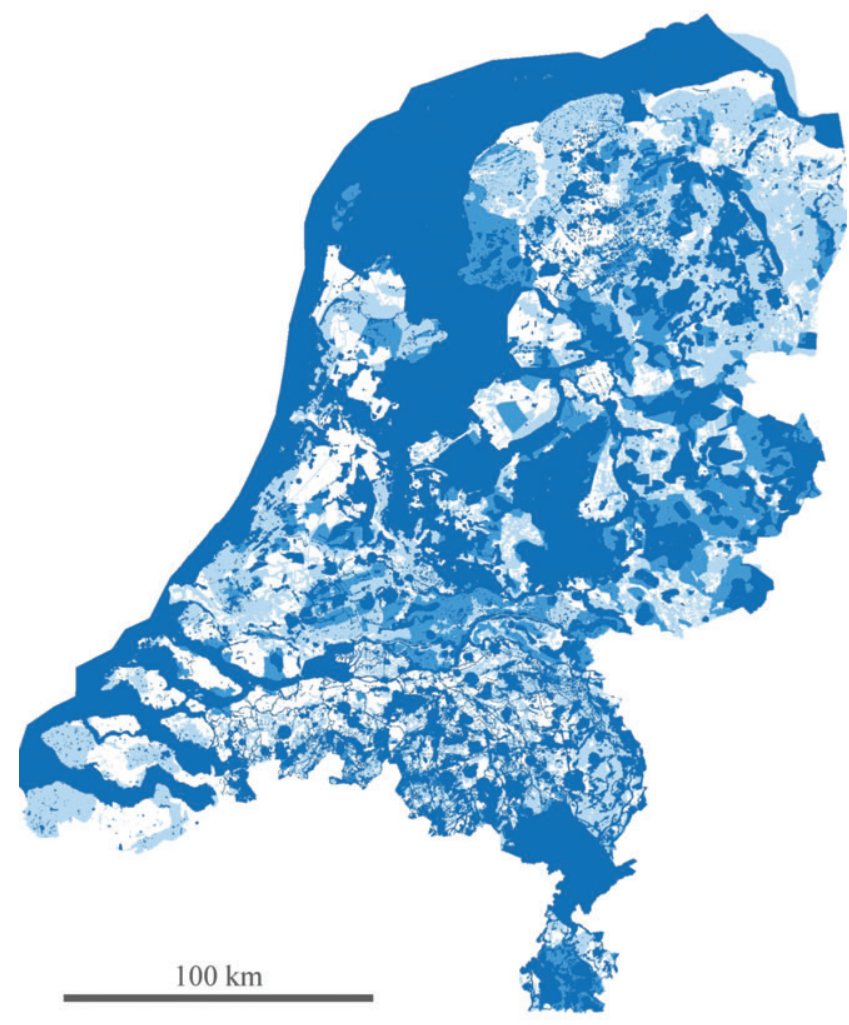

Fig. 17. Area limitations for exploration in the Netherlands. Dark-blue: Nature Reserves (MER obligatory); medium-blue: 'aandachtsgebieden' (areas of attentian); light-blue: built-up areas.

Development of unconventional gas however requires a multitude of wells with dense spacing. In the combined BCG/CBM play in the San Juan Basin in Colorado some 38,000 wells have been drilled in an area of about one third of the onshore Netherlands!

As another example, in the very prolific Barnett Shale gas play in North Texas the average recovery per (horizontal) well is $0.03 \mathrm{bcm}$ with a drainage area of $0.6 \mathrm{~km}^{2}$ and a relatively short production life of 7-10 years with flowrates in the order of $10,000 \mathrm{~m}^{3} /$ day (Berman, 2009). This means that development of a typical sweetspot with UR of $10 \mathrm{bcm}$, some 300 wells would be required on an area of $20 \mathrm{~km}^{2}$ and their total daily production would equal that of one 'good' Groningen well. Obviously, this would have a high impact on the surface expression of such a development, even with multilateral wells. In the onshore Netherlands it will be almost impossible to fit such infrastructure in the landscape, even outside built-up areas and nature reserves. This presents a big challenge for the development of longreach, low-impact drilling technology as well as engineering solutions which render production stations 'invisible'. It is therefore strongly recommended that in the pursuit of unconventional gas in the Netherlands, equal priority is given to subsurface resource assessment and surface/drilling engineering solutions.

\section{Discussion}

A recently issued report by Energie Beheer Nederland (2009), which is based on a TNO report by Muntendam-Boset et al. (2009) has received extensive media attention during summer 2009 as it quotes very large volumes for Unconventional gas resources in the Netherlands.

What was generally not very evident in the media attention was that the reported volumes relate to in-place volumes only and do not make a distinction between the on- and offshore. Nevertheless, it is the opinion of the authors that the reported in-place volumes are unrealistically high and, for several reasons, these numbers cannot be taken as an indication of volumes that may be recoverable in the future. For a realistic assessment of unconventional gas resources the following should be taken into account:

1. Unconventional gas volumes in the offshore will not be commercial for many decades to come, since costs of drilling, infrastructure and OPEX per $\mathrm{m}^{3}$ are prohibitively high. Even if in the future offshore development of unconventional gas would be more efficient, this will then be when infrastructure has been dismantled, making most of the remaining offshore portfolio sub-economic.

2. The Westphalian sequence might render the only commercially viable option for a BCG system, but it has been tested negative in several wells. Post-Carboniferous sequences are very unlikely to present viable BCG resource volumes.

3. Only BCG systems that experienced late uplift (structural inversion) are likely to be able to produce at commercial rates and deliver sufficient volumes per well.

4. The SG volumes should not include thick low TOC formations, such as the Epen and Aalburg Formations, for which there is no analogue, and which cannot be assumed to represent realistic targets from which gas can be produced commercially.

5. Only gas mature source rocks can be considered for SG resources.

6. CBM resource estimates can include only volumes situated shallower than $1500 \mathrm{~m}$. For deeper CBM systems commercial production is extremely unlikely (all known developments are from depths shallower than $1200 \mathrm{~m}$ ).

7. Development of unconventional gas resources typically relies on finding sweet spots from where commercial flow-rates and EUR per well can be achieved. Only a fraction of the assumed area may end up being commercially developable.

8. Surface conditions may be prohibitive in large parts of the Netherlands.

9. Unconventional plays are still unproven in the Netherlands and the chance of commercially developable gas for all considered unconventional types is very low. 


\section{Conclusions}

The Netherlands represents a very mature area for oil and gas exploration. Technology developments will continue to improve the accuracy of the evaluation of the subsurface, and will allow drilling of smaller and smaller targets by lowering the economic cut-off. And although it is likely that new discoveries will continue to be made in the short to medium future, it is unlikely that significant new exploration finds will be made in conventional traps. The currently published undiscovered conventional exploration potential of $170-380 \mathrm{bcm}$ seems overestimated and if we don't find more gas per year than we have done in the last few years ( 5 and $3 \mathrm{bcm}$ in 2007 and 2008 respectively), it will take (much) more than 30 years to realize it. For the offshore this will then to a large extent be when infrastructure has been dismantled, making most of the remaining offshore portfolio sub-economic.

The potential of so-called unconventional hydrocarbon resources is very uncertain and the presence of unconventional resources is still unproven in the Netherlands. It is unlikely that there is potential for Basin Centred Gas in deeper parts of the Westphalian, but even in case of success, the recoverable volume will not exceed several 10's of bcm. The potential for Shale Gas resources is limited to the Namurian Geverik Shale in the far south of the Netherlands (Peel area) with a potential recoverable volume of $10-20 \mathrm{bcm}$. There is a reasonable likelihood of potential for Coal Bed Methane where the top Westphalian is sufficiently shallow, less than $1500 \mathrm{~m}$, in the far east (Achterhoek) and south (Peel area), but its potential recoverable volume will not exceed $30 \mathrm{bcm}$. Therefore the total (unrisked) technically recoverable volume for unconventional gas in the Netherlands ranges from a few tens to one or two hundreds of bcm at best.

Even if some of these unconventional plays can be proven, commercial development is typically only possible in some sweet spots, which represent only a fraction of the total play area. Well flow rates and ultimate recovery per well must be sufficient and in balance with drilling, completion and development costs. A very serious societal concern is the footprint of unconventional gas production systems. Development requires very high well densities, as drainage areas are typically less than $1 \mathrm{~km}^{2}$ per well. Even with multi-lateral wells, in most parts of the country development will not be possible because of unacceptable impact on the environment. A break-through in surface and drilling engineering is required before unconventional resources can be exploited at a scale large enough to have some impact on the gas reserves outlook for the Netherlands.

In conclusion, the authors believe that in a mature area like the Netherlands, industry focus should be on technology development to reduce risk, increase recovery, reduce cost and minimize surface impact. Government incentives should be targeted at the development phase, in order to increase economic attractiveness for difficult reservoirs, both conventional and unconventional. In this way State and industry will both be able to maximize their returns on the remaining potential for gas and oil in the next two to three decades.

\section{Acknowledgements}

This paper is published by permission of the Nederlandse Aardolie Maatschappij BV (NAM), Shell Internationale Petroleum Maatschappij BV and ExxonMobil. The authors gratefully acknowledge Mark Geluk for his constructive and valuable comments, Bram Bruijn for his critical examination of the manuscript, and Wicher van Lingen, Jenet Lea and Joost van Arendonk for help with some of the figures.

\section{References}

Ayers, W.B.Jr, 2002. Coalbed gas systems, resources and production and a review of contrasting cases from San Juan and Powder basins. AAPG Bulletin 86: $1853-1890$

Berman, A., 2009. Lessons learnt from the Barnett Shale. World oil Magazine, August 2009.

Biteau, J.J., 2009. 45 years of Total. Symposium Fifty years of petroleum exploration in the Netherlands after the Groningen discovery - 15 and 16 January 2009. Available from: www.nlog.nl/nl/pubs/reports/presentations. $h$ tml

Bokhoven, J.D., 2009, Best access to Dutch gas, EBN presentation at the Deloitte seminar, Amsterdam 14 $4^{\text {th }}$ May 2009. Accessible through: www.ebn.nl/ presentaties.php?29.

Bruehl, M., Spaargaren B., Van Spaendonck, R. \& Van Lingen W., 2008. Highgrading the prospect portfolio with latest technology - Impact on southern Permian Basin. Paper presented at the 2008 EAGE Annual Conference, Rome.

Chakhmakhchev, A., 2007. Worldwide coalbed methane overview. SPE 106850. Paper presented at the 2007 SPE hydrocarbon economics and evaluation symposium, 1-3 April, Texas, USA.

Curtis, J.B., 2002. Fractured shale-gas systems. AAPG Bulletin 86: 1921-1938

Curtis, J.B., 2009. The Contribution of Shale Gas to Future U.S. Production: A View of the Resource Base. Search and Discovery Article \#110082.

De Jager, J., Doyle, M.A., Grantham, P.J., \& Mabillard, J.E., 1996. Hydrocarbon habitat of the West Netherlands Basin. In: Rondeel, H.E., Batjes, D.A.J. \& Nieuwenhuijs, W.H. (eds): Geology of gas and oil under the Netherlands. Kluwer (Dordrecht): 191-209.

De Jager, J., 2003. Inverted basins in the Netherlands, similarities and differences. Netherlands Journal of Geosciences 82: 339-349

De Jager, J \& Geluk, M.C., 2007. Petroleum Geology. In: Wong, Th.E., Batjes, D.A.J. \& De Jager, J. (eds): Geology of the Netherlands. Royal Netherlands Academy of Arts and Sciences: 241-264.

De Wijn, B., 2009. Wintershall exploration and production history. Symposium Fifty years of petroleum exploration in the Netherlands after the Groningen discovery, 15 and 16 January 2009. Available from: www.nlog.nl/nl/pubs/ reports/presentations. html

Energie Beheer Nederland (EBN), 2009. Focus on Dutch Gas, EBN Jaarverslag 2009. 
Hood, K.C. \& Yurewicz, D.A., 2008. Assessing the Mesaverde basin-centered gas play, Piceance Basin, Colorado. In: Cumella, S. P., Shanley, K. W. and Camp, W. K. (eds): Understanding, exploring, and developing tight-gas sands, 2005, Vail Hedberg Conference: AAPG Hedberg Series 3: 87-104.

Huffman, A.C. Jr, 2003. San Juan Basin Province. Mexico Bureau of Geology and Mineral Resources 0pen-file report 464, 33 p., 1 appendix. Available from: certmapper.cr.usgs.gov/data/noga95/prov22/text/prov22/pdf

Jarvie, D.M.. Hill, R.J., Ruble, T.E. \& Pollastro, R.M., 2007. Unconventional shale-gas systems: the Mississippian Barnett Shale of north-central Texas as one model for thermogenic shale-gas assessment. AAPG Bulletin 91: 475-499.

Kombrink, H., 2008. The Carboniferous of the Netherlands and surrounding areas; a basin analysis, Geologica Ultraiectina 294, 184 pp.

Law, B.E., 2002. Basin-centered gas systems: AAPG Bulletin 86: 1891-1919.

Law, B.E., 1984. Relationships of source-rock, thermal maturity, and overpressuring to gas generation and occurrence in low-permeability Upper Cretaceous and lower Tertiary rocks, Greater Green River basin, Wyoming, Colorado, and Utah. In: Woodward, J., Meissner, F. F. \& Clayton, J. L. (eds): Hydrocarbon source rocks of the greater Rocky Mountain region: 1984 Rocky Mountain Association of Geologists Guidebook: 469-490.

Masters, J.A., 1984. Lower Cretaceous oil and gas in Western Canada. In: Masters, J.A. (ed.): Elmworth: Case Study of a Deep Basin Gas Field. AAPG Memoir 38: $1-33$.

Masters, J A., 1979. Deep basin gas trap, Western Canada. AAPG Bull 63: 152-181. Ministry of Economic Affairs, 2009. Delfstoffen en aardwarmte in Nederland Jaarverslag 2008, 145 pp. (available from: www.nlog.nl/nl/pubs/ publications.html).

Muntendam-Bos, A.G., Wassing, B.B.T., Ter Heege, J.H., Van Bergen, F., Schavemaker, Y.A., Van Gessel, S.F., De Jong, M.L., Nelskamp Dipl.- Geow, S., Van Thienen-Visser, K., Guasti, E., Van den Belt, F.J.G. \& Marges, V.C., 2009. Inventory non-conventional gas, TNO report: TNO-034-UT-200900774/B (Utrecht), 188 pp. Available from: www.ebn.nl/files/ ebn_report_final_090909.pdf

Nederlandse Aardolie Maatschappij (NAM), 2006. Milieu Effect Rapport Herontwikkeling olieveld Schoonebeek.

Pollastro, R.M., Hill, R.J., Jarvie, D.M. \& Henry, M.E., 2003. Assessing Undiscovered Resources of the Barnett-Paleozoic Total Petroleum System, Bend Arch-Fort Worth Basin Province, Texas. Southwest Section of AAPG Transactions, 18 pp. CD-ROM

Shanley, K.W., Cluff, R.M. \& Robinson, J.W., 2004. Factors controlling prolific gas production from low-permeability sandstone reservoirs: implications for resource assessment, prospect development and risk analysis. AAPG Bulletin 88: 1083-1121.

U.S. Geological Survey, 2002. Assessment of Undiscovered Oil and Gas Resources of the San Juan Basin Province of New Mexico and Colorado. U.S. Geological Survey Fact Sheet 147-02.

Van Balen, R.T., Van Bergen, F., De Leeuw, C.S., Pagnier, H.J.M., Simmelink, H.J., Van Wees, J.D.A.M. \& Verweij, J.M., 2000. Modelling the hydrocarbon generation and migration in the West Netherlands Basin, the Netherlands. Geologie en Mijnbouw / Netherlands Journal of Geosciences 79: 29-44.
Van Bergen, F., Pagnier, H.J.M., David, P. \& Krooss, B.M., 2000. Inventory of potential volumes of methane extraction and carbon-dioxide storage in coallayers in the Dutch subsurface. TN0 contribution to the 'Feasibility study of combined Coalbed Methane production and Carbon Dioxide storage in the Netherlands'. TN0 report NITG-00-272-B (Utrecht), 87 pp.

Van Bergen, F., Pagnier, H.J.M. \& Van Tongeren, P.C.H., 2007. Peat, coal and coalbed methane. In: Wong, Th.E., Batjes, D.A.J. \& De Jager, J. (eds): Geology of the Netherlands. Royal Netherlands Academy of Arts and Sciences: 265-282.

Van Buggenum, J.M. \& Den Hartog Jager, J. \& Silesian, D.G., 2007. In: Wong, Th.E., Batjes, D.A.J. \& De Jager, J. (eds): Geology of the Netherlands. Royal Netherlands Academy of Arts and Sciences (Amsterdam): 43-62.

Van der Kolk, C.M., Guest, W.S. \& Potters, J.H.H.M., 2001. The 3D shear experiment over the Natih field in Oman: the effect of fracture-filling fluids on shear propagation. Geophysical Prospecting, 49: 179-197.

Van der Molen, A.S., 2004. Sedimentary development, seismic stratigraphy and burial compaction of the Chalk Group in the Netherlands North Sea area. PhD thesis, University of Utrecht. In: Geologica Ultrajectina, Mededelingen van de Faculteit Geowetenschappen Universiteit Utrecht 248, 175 pp.

Wolf, K.-H.A.A., Westerink, H.H.E., Van Delft, P.T.P. \& Bruining, J., 1997. Coalbed Methane Production in the Netherlands: An Inventory. Delft University of Technology, TUD-code: TA/PF/97.004, 73 pp.

Wong, Th.E., 2007. Jurassic. In: Wong, Th.E., Batjes, D.A.J. \& De Jager, J. (eds): Geology of the Netherlands. Royal Netherlands Academy of Arts and Sciences (Amsterdam): 107-125.

Yurewicz, D.A., Bohacs, K.M., Kendall, J., Klimentidis, R.E., Kronmueller, K., Meurer, M.E., Ryan, T.C. \& Yeakel, J.D., 2008. Controls on gas and water distribution, Mesaverde basin-centered gas play, Piceance Basin, Colorado. In: Cumella, S.P., Shanley, K.W. \& Camp, W.K. (eds): Understanding, exploring, and developing tight-gas sands, 2005. Vail Hedberg Conference: AAPG Hedberg Series 3: 105-136. 